\title{
POPULATION PROCESSES AND STRUCTURES IN THE URBAN AND RURAL SPACES OF SLOVAKIA
}

\author{
Jozef Mládek ${ }^{1}$ - Katarína Čupel'ová ${ }^{2}$
}

Received 14 July 2009; Accepted 3 June 2010

\begin{abstract}
The aim of the study is to analyze the distinctions in the demographic behaviour and in the formation of the urban and rural population structures. They are two different population sets following their specific rules. In the more conservative countryside there applies the effect of traditions and customs, in the towns there are more visible trends of modern societies, as e.g. the secularisation, individualization etc. Towns are characterised by reducing intensity of fertility. There is preferred the model of the late marriage and the model of the one-child family. So far the rural population realises its fertility already in lower age groups and family model is mainly twochildren. In urban milieu there are more informal family partnerships - cohabitations. There is also the higher incidence of the negative population phenomena - divorces and abortions. Formation of the population structures is also dependent on the scale of the settlement and the structures in the urban and rural settlements are different as well. There have formed younger population age structures in the towns, ageing processes are more intensive in the villages and especially in the smallest settlements. The towns and especially the largest of them have more favourable education population structure.
\end{abstract}

Keywords: demographic behaviour, rural and urban population, natality, mortality, marriage, divorce, sex and age structure, religion, ethnic, education structure of population

\begin{abstract}
Abstrakt: Populačné procesy a štruktúry $v$ urbánnych a rurálnych priestoroch Slovenska. Príspevok analyzuje rozdiely $v$ demografickom správaní a vo formovaní populačných štruktúr mestského a vidieckeho obyvatel'stva. Sú to dva odlišné populačné súbory riadiace sa vlastnými zákonitost’ami. Na konzervatívnejšom vidieku sa uplatňuje vplyv tradícií, zvykov, v mestách sa uplatňujú súčasné trendy modernej spoločnosti, ako sú sekulárizácia, nárast individualizmu a d’alšie. V mestách sa znižuje intenzita plodnosti, posúva sa vyššieho veku. Je preferovaný model neskorej sobášnosti a model jednodetnej maximálne dvojdetnej rodiny, zatiat' čo vidiecke obyvatel'stvo svoju plodnost' realizuje už $v$ nižšom veku a model rodiny je prevažne dvoja viacdetný. $\mathrm{V}$ mestskom prostredie je viac neformálnych partnerských zväzkov kohabitácií. Väčší výskyt majú negatívne populačné javy - rozvodovost' a potratovost'.Aj formovanie štruktúr obyvatel'stva je závislé na vel'kosti obce
\end{abstract}

\footnotetext{
1 Prof. RNDr. Jozef MLÁDEK, DrSc., Katedra humánnej geografie a demogeografie, Prírodovedecká fakulta Univerzity Komenského v Bratislave. mladek@fns.uniba.sk,

${ }^{2}$ Mgr. Katarína ČUPEL'OVÁ, Katedra regionálnej geografie, ochrany a plánovania krajiny, Prírodovedecká fakulta Univerzity Komenského v Bratislave. cupelova@fns.uniba.sk
} 
a odlišujú sa i štruktúry mestských a vidieckych sídiel. V mestách sa sformovali mladšie vekové štruktúry obyvatel'stva, procesy starnutia sú intenzívnejšie na vidieku a najmä v najmenších sídlach. Mestá a predovšetkým skupina najväčších miest má priaznivejšiu vzdelanostnú štruktúru obyvatel'stva.

Kl'účové slová: demografické správanie, vidiecké a mestské obyvatel'stvo, natalita, mortalita, manželstvo, rozvod, pohlavná a veková štruktúra, relígia, etnická a vzdelanostná štruktúra populace

\section{Introduction}

The basic potencial of the region contains its social and human capacities. It represents the main source of territorial development, but also the factor of regional disparities (Blažek, 1987).

Concept of human capital was at first identified by Becker (1962) with benefits from such investment in people as education, training and health. Presently, the human capital is the most often determined as knowledge, skills, competence and other attributes embodied integrated in a human being that enable establishment of personal, social and economical prosperity (OECD, 2001). In 1988 Coleman defines the social capital as the ability of people to work together in frames of group and organization in order to realize common purposes. Other authors besides of him was Putman (1995), Fukuyama (1995, 1997) and Portes (1998 in Janc, 2006).

Slovak society has recently undergone significant social changes. After 1989 started in Central and Eastern Europe transformation, the beginning was marked by significant political changes. Turnovers in political institutions were quickly followed by those in economic institutional arrangements as well as cultural institutionals arrangements and those in human potencial. (Moravanská, 2005). Turnaround in long-term population processes in Central and Eastern European countries changed the population-redistribution patterns. Depopulation of rural areas came to the end and moderate growth of rural population began because of deurbanization (Billari, Kulu, 2006). Industrial urbanization and quantitative concentration of citizens into towns have been suppressed. Changed values have been induced mainly by the ecological crisis, development of communication technologies and institutional changes in society (Beck, 2004). Qualitative concentration of human, social, economic and infrastructural potential in towns ceased to motivate development in society and countryside underwent renaissance (IIIner, 1992).

Internal migration in Slovakia changed rapidly in the period of transformation. In the period 1950-1980, the percentage of urban population doubled. Development and characteristics of the internal migration have been most significantly influenced by industrialization, intensification of agriculture, construction of dwellings in cities, and from the mid 1970s, by implementation of the centralized system of settlement, which strengthened the growth of selected communes (settlement centres) and limited that of small communes by blocking their construction of new dwellings. Regions with higher population and higher level of natural reproduction (north and east of the country) were source areas with the distinct migration losses. Hence, differentiation of migration was the result of not only natural attraction of the individual regions, but also different (sometimes questionable) preferences and compensations. The rural population moved above all to district cities, or to the nearest central communes. The concentration nature of migration in Slovakia manifested most intensively in the course of the 1970s and approximately until the mid-1980s when the extensive phase of urbanization in Slovakia culminated.

Apart from an extra rapid growth of urban population, the result of migration was the depopulation of rural regions and subsequent changes of their functions including changes in population structure and of demographic potential in different areas of the country.

The internal migration of the SR in the 1990s has been gradually losing is concentration character and deconcentrating tendencies prevailed. Living in small communes and in hinterland of big and medium sized cities is becoming more attractive. Basic characteristic of internal migration is the change of the net migration in the size categories of communes 
(Jurčová D. In: Atlas obyvatel'stva Slovenska, p. 67). While cities with population over 10 thousand the biggest increases before the beginning of the 1990s was observed and communes with population 5 to 10 thousand also registered some migration increases, small communes with population below 2 thousand suffered migration losses for a long time. The principal change came around 1995. Migration losses of the smallest communes have first rapidly dropped and since 1996 these communes (population below 2 thousand) gain, the same as the communes with the population below 5 thousand. However, their geographic position is very important. The communes that gain most by migration are those in the hinterland of big cities. Migration increase of small communes is partially due to the relatively complicated acquisition of a new dwelling (mainly because of their price in cities), what eventually represents an obstacle in migration.

On the other hand, cities with population over 10 thousand have enjoyed a consistent migration loss since mid 90s. The reduction of construction after 1990, high prices of flats and often not clear legal rules in the sphere of dwellings are the obstacles barriers in the proper functioning of the real estate market and migration options. (Podolák P. In: Demographical Analysis of Slovakia 2006, p. 76).

Differences in demographic behaviour of population and formation of population structures in urban and rural settlements appeared already in remote past practically when the first cities sprang. Living conditions of population had become different in many aspects, and they continue changing with the developing social formations. Effects of several specific features proper to rural or to urban space population can be still observed nowadays. They include:

- Structure and orientation of population's economic activities (productive and above all non productive ones) and the resulting differences in professional structure of population;

- Differences in social structure of population (rural population groups are more homogeneous);

- Differences in population density and the resulting spatial requirements and problems;

- Stronger effects of traditions and usage (often caused by more intensive religiousness) in rural area;

- Greater anonymity, individualism, secularisation taking effect on demographic behaviour of urban population;

- Differences in housing level and living styles;

- Differences in migration mobility of population.

The aim of this paper is to present some results of a wider study devoted to different demographic behaviour and formation of different population structures in conditions of rural and urban areas of Slovakia.

\section{Methodology}

One of the key questions in the study of the quoted issues was the classification of settlements into rural and urban ones. The most often used criteria are those concerning size (statistical) administrative (historic and legal) and the criterion of population density. In Slovakia, a comprehensive criterion of evaluation is applied. It assesses the economic, cultural, and administrative functions of a settlement, its transport position, amenities, services, character of urban coverage, and population number ( 5 thousand at least). Settlements that meet the criteria win the statute of a city (the National Council of the Slovak Republic concedes the statute of a city following the proposal presented by the Government) In 2001, 138 settlements were recognized cities. Rural settlements represent a more populous group amounting to 2,745. Population of $3,022,106$ lived in cities what represents $56.18 \%$ of total population (level of urbanization). Based on such classification of settlements and population, the involved processes and structures in Slovakia were analysed.

The second classification of settlements was carried out pursuing the criterion of population number and analysis of demographic behaviour and population structures, which were assessed pursuing the size categories of settlements. 
Databases for the assessment of population structure were compiled from the data drawn from the 2001 Census of populations, houses and flats. Population processes were assessed from the Population status and change in the Slovak Republic. In efforts to increase the statement value of the statistical data at the level of municipalities, average data from 2001-2003 were applied.

\section{Specific features of urban and rural populations' demographic behaviour}

The natural and mechanical population change is determined by a big group of factors among which economic conditions, ethnic and religious structures, traditions in reproductive behaviour and many others are considered most important. An important role is attributed precisely to urbanizing processes or to the level of urbanization reached (urbanization theory).

\subsection{Natality and fertility rates}

The mean crude rate of live births in 2001-2003 reached $9.5 \%$ in Slovakia while higher level was recorded among rural population (10.5\%o). In terms of size categories of municipalities, the top values were reached in those with population from 500 to 5 thousand and the lowest values were observed in cities with population more than 50 thousand (tab. 1). Differences between the values of standardized gross rate of live births in rural and urban populations are even more conspicuous because the effect of age structure in these sets was removed. Likewise, values in individual size categories (higher live birth rates in municipalities with population below 5,000 and the highest rate $(11.8 \%$.) in municipalities with population below 200)) also changed.

\begin{tabular}{|c|c|c|c|c|c|c|c|}
\hline & $\begin{array}{l}\text { Standardised } \\
\text { crude live birth } \\
\text { rate }(\% o)^{1)}\end{array}$ & $\begin{array}{c}\text { Crude live } \\
\text { birth rate } \\
(\%)\end{array}$ & $\begin{array}{c}\text { Share of children } \\
\text { born out } \\
\text { of wedlock }(\%)^{2)}\end{array}$ & $\begin{array}{c}\text { General fertility } \\
\text { rate }(\% o)^{3)}\end{array}$ & $\begin{array}{c}\text { Total fertility } \\
\text { rate }\end{array}$ & $\begin{array}{c}\text { Average order } \\
\text { of live births }\end{array}$ & $\begin{array}{c}\text { Average age } \\
\text { of mother }\end{array}$ \\
\hline urban & 8,49 & 8,77 & 22,24 & 30,64 & 1,08 & 1,85 & 26,69 \\
\hline rural & 10,93 & 10,48 & 20,87 & 42,53 & 1,38 & 2,18 & 25,66 \\
\hline 0-199 & 11,77 & 9,55 & 21,77 & 46,31 & 1,49 & 2,22 & 25,81 \\
\hline $200-499$ & 10,58 & 9,66 & 20,05 & 41,16 & 1,33 & 2,13 & 25,77 \\
\hline $500-999$ & 11,18 & 10,40 & 21,24 & 43,30 & 1,40 & 2,17 & 25,62 \\
\hline 1000-1999 & 10,80 & 10,43 & 20,59 & 41,84 & 1,36 & 2,18 & 25,65 \\
\hline $2000-4999$ & 11,21 & 11,02 & 21,68 & 43,45 & 1,41 & 2,22 & 25,68 \\
\hline $5000-9999$ & 9,34 & 9,53 & 23,41 & 34,77 & 1,18 & 2,03 & 25,90 \\
\hline $10000-19999$ & 8,67 & 9,12 & 23,69 & 31,90 & 1,10 & 1,89 & 26,21 \\
\hline $20000-49999$ & 8,34 & 8,78 & 22,39 & 30,16 & 1,06 & 1,86 & 26,48 \\
\hline $50000-99999$ & 8,08 & 8,36 & 18,65 & 28,77 & 1,03 & 1,75 & 26,96 \\
\hline $100000+$ & 8,18 & 8,36 & 22,89 & 29,22 & 1,05 & 1,75 & 27,58 \\
\hline Slovakia & 9,52 & 9,52 & 21,58 & 35,44 & 1,20 & 2,01 & 26,19 \\
\hline
\end{tabular}

1) Indirect standardisation

2) Share of total births

3) Number of live births per 1000 females in reproductive age (15 - 49 years)

Tab 1. Natality and fertility indicators of Slovak population (average of $2001-2003$ ).

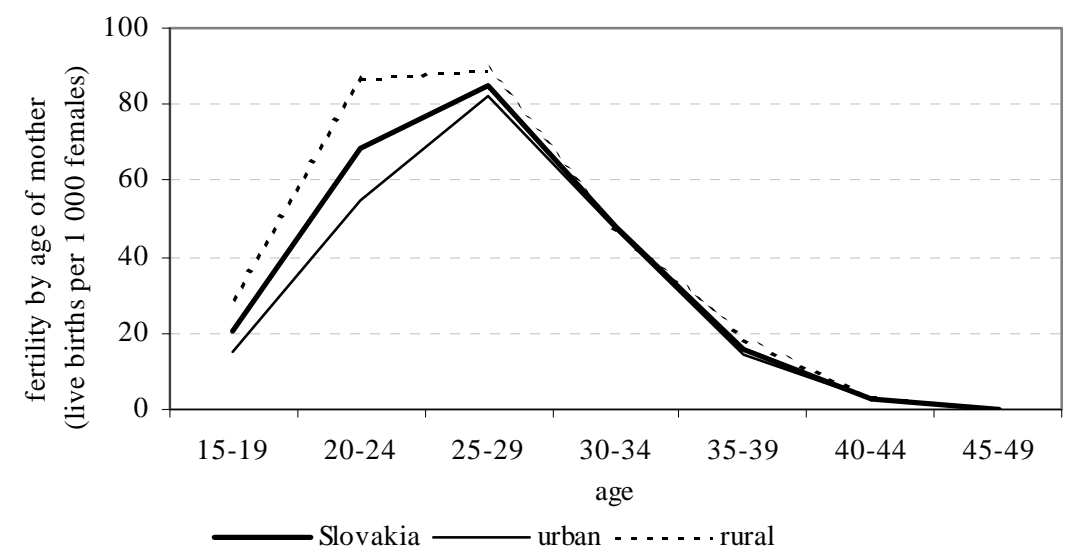

Graph 1. Fertility by age of mother - urban and rural population of Slovakia (average of 2001 - 2003).

Values in the remaining smaller municipalities are underestimated in a similar way. In the consequence of a favourable age structures, cities and bigger municipalities display high 
live birth rates, but their fertility rate is actually lower. The lowest values $(8,1 \%)$ were observed in cities with population from 50,000 to 100,000 . More favourable situation was found in the biggest cities of Košice and Bratislava, where the live birth rate reaches $8.2 \%$.

Specific fertility rates by mother's age show that the maximum fertility of urban population is distinctly shifted to the 25-29-year category of females (graph 1) while in rural area it still dwells at the 20-24-year age category. Similar differences are observable in assessment of fertility in size categories of settlements (graph 2). The model of earlier fertility (20-24-year age categories and even higher fertility in the 19-year age category) still survives in smaller settlements while the maximum fertility in bigger settlement is in the category of 25-29-year old females.

The percentage of births out of the wedding lock in Slovakia was $21.6 \%$ in concerned period. The figure was higher for urban population $22.2 \%$ proving the presumption that the bonds between the reproductive and marital behaviour in urban environment are slackening (Mládek, Marenčáková, Širočková 2006). The highest percentage was found in municipalities with population number from 1 thousand to 20 thousand.

Total fertility rate which best captures the rate of population fertility in Slovak cities reached 1.08 in 2001-2003 while in rural area it was 1.38 children. Values of overall fertility drop with the increasing size of municipality. They dropped below the national average (1.2) and even below the lowest - low fertility 1.3 in municipalities with population over 50,000.

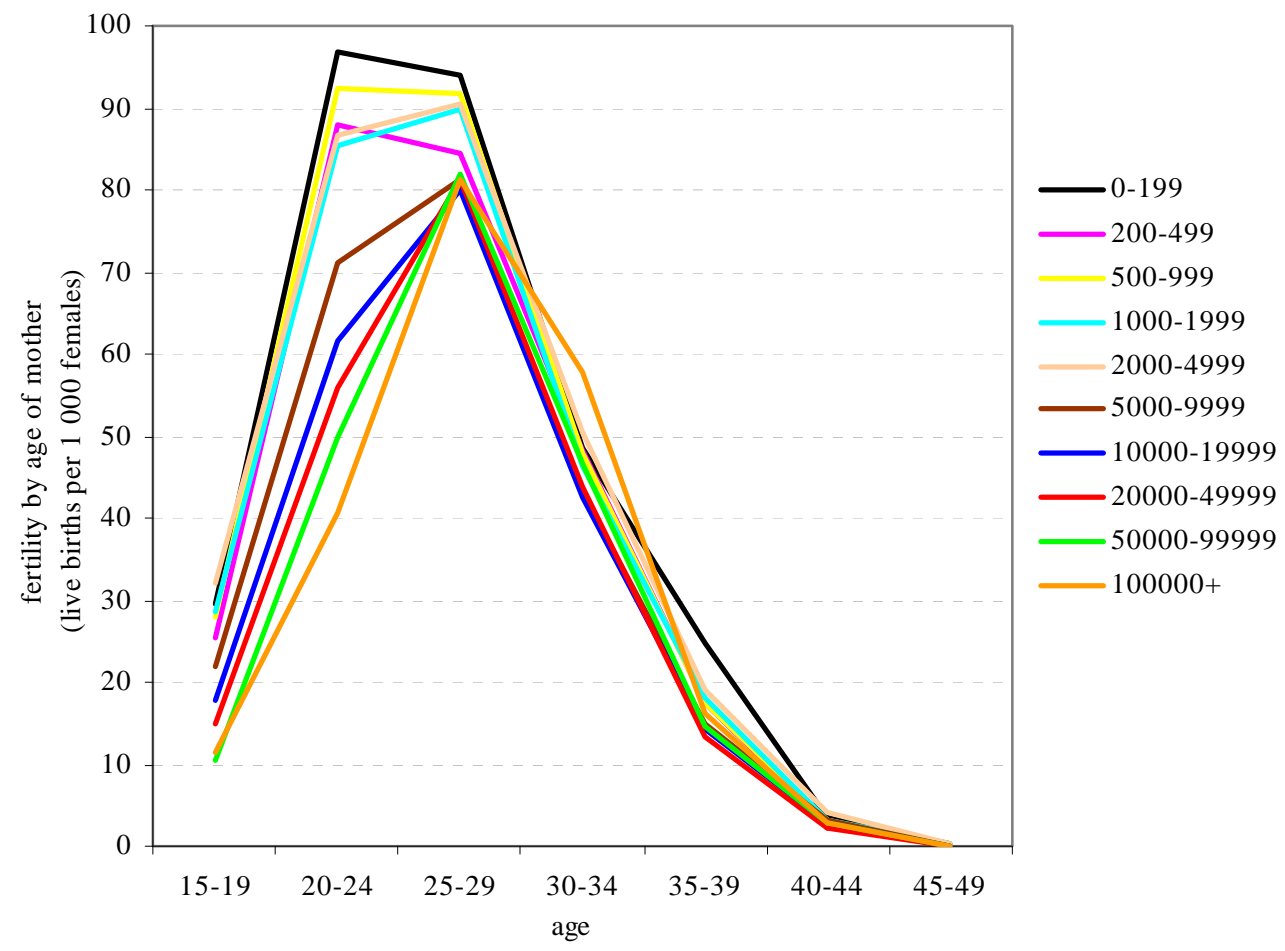

Graph 2. Fertility by age of mother - communes of Slovakia (average of 2001 - 2003).

Changes in timing of fertility are also suggested by the mean age at birth giving. It is higher in the cities (26.7 years) than in the rural area (25.7 years). The increasing size of municipality is accompanied by the average age of mother at birth, while the highest age at birth was observed in our biggest cities (27.6 years). Higher than average values were already found in cities with population over 10,000 .

\subsection{Mortality}

Differences in the crude death rate is greatly determined by the population age structure which reflects both the long- and short-term changes in natality rate but is also influenced by the migration level connected with the economic and social situation in individual sets of municipalities. The mortality level depends on sex structure of population because of different mortality of males and that of females, on family status, education, ethnicity, and religion (Mládek a kol. 2006). 
The ageing process in municipalities with low live birth rate is quicker; the share of older population increases and the result is a higher crude mortality rate as obvious from table 2 . Values high above the national average are reached in rural municipalities as a whole or in groups of municipalities with population below 5 thousand. The lowest mortality rate was found for municipalities with population from 50 thousand to 100 thousand. Top values of the standardised rate were reached in municipalities with population between 500 and 20 thousand. The smallest municipalities with population below 200 and the cities with population over 20 thousand display values below the national average. In case of cities, those with population between 50 thousand and 100 thousand followed by Košice and Bratislava reached the lowest mortality rates. Values of infant mortality (lower in urban municipalities than in rural areas) also talk about health service quality and the level of living standard. High values in the rural area are presumably determined by age structure of mothers at childbirth (they are often older) and their ethnic and educational levels (for instance in municipalities with population 2 to 5 thousand with high share of the Roma ethnicity). A more difficult access to health service in such municipalities also plays a role.

\begin{tabular}{|c|c|c|c|c|c|c|c|c|c|c|c|c|}
\hline & \multirow{3}{*}{$\begin{array}{c}\text { Crude } \\
\text { death rate } \\
(\%)\end{array}$} & \multirow{3}{*}{$\begin{array}{c}\text { Standardised } \\
\text { crude death } \\
\text { rate }(\%)^{1)}\end{array}$} & \multirow{3}{*}{$\begin{array}{c}\text { Infant } \\
\text { mortality } \\
\text { rate (\%o) }\end{array}$} & \multirow{3}{*}{$\begin{array}{c}\text { Neonatal } \\
\text { mortality } \\
\text { rate (\%o) }\end{array}$} & \multicolumn{8}{|c|}{ Share of deaths by cause of death (\%) } \\
\hline & & & & & \multicolumn{4}{|c|}{ Females } & \multicolumn{4}{|c|}{ Males } \\
\hline & & & & & IX. & II. & X. & XI. & IX. & II. & XX. & XI. \\
\hline urban & 8,26 & 9,06 & 6,49 & 4,13 & 58,3 & 22,2 & 5,2 & 4,4 & 46,7 & 25,8 & 9,5 & 6,1 \\
\hline rural & 11,41 & 10,27 & 8,04 & 4,78 & 65,5 & 17,4 & 5,3 & 3,8 & 49,2 & 24,1 & 8,3 & 6,3 \\
\hline 0-199 & 15,97 & 9,47 & 9,76 & 4,50 & 69,6 & 15,5 & 5,7 & 2,8 & 54,0 & 23,3 & 6,3 & 5,2 \\
\hline $200-499$ & 13,26 & 9,91 & 8,26 & 5,51 & 67,8 & 16,8 & 4,8 & 3,4 & 51,4 & 23,9 & 7,4 & 6,1 \\
\hline $500-999$ & 11,97 & 10,15 & 8,13 & 4,84 & 66,6 & 16,9 & 4,8 & 3,8 & 50,3 & 23,7 & 7,6 & 6,3 \\
\hline 1000-1999 & 11,00 & 10,97 & 7,64 & 4,67 & 64,8 & 18,1 & 5,1 & 3,6 & 49,1 & 24,2 & 8,7 & 6,3 \\
\hline $2000-4999$ & 10,50 & 10,36 & 9,03 & 5,35 & 64,0 & 17,6 & 6,0 & 4,1 & 47,1 & 24,7 & 8,8 & 6,5 \\
\hline $5000-9999$ & 9,24 & 10,20 & 6,69 & 3,99 & 62,4 & 18,9 & 5,1 & 3,9 & 46,6 & 24,5 & 9,9 & 5,8 \\
\hline 10000-19999 & 8,41 & 10,06 & 7,08 & 4,58 & 60,6 & 20,6 & 5,1 & 4,0 & 46,7 & 25,1 & 9,7 & 6,8 \\
\hline $20000-49999$ & 7,97 & 9,51 & 5,86 & 3,45 & 58,7 & 21,4 & 5,5 & 4,4 & 47,2 & 25,2 & 9,3 & 6,1 \\
\hline 50000-99999 & 7,31 & 8,35 & 5,82 & 4,27 & 56,3 & 23,5 & 5,7 & 4,3 & 44,9 & 27,1 & 9,7 & 5,4 \\
\hline $100000+$ & 8,78 & 8,58 & 6,13 & 3,55 & 55,2 & 25,0 & 4,8 & 5,2 & 47,2 & 26,4 & 9,3 & 6,1 \\
\hline Slovakia & 9,65 & - & 7,24 & 4,44 & 62,0 & 19,7 & 5,3 & 4,1 & 48,0 & 24,9 & 8,8 & 6,2 \\
\hline
\end{tabular}

1) Indirect standardisation

Causes of death: II. Tumours

IX. Diseases of circulatory system

X. Diseases of the respiratory system

XI. Diseases of digestive system

$\mathrm{XX}$. Injury and poisoning

Tab 2. Mortality indicators of Slovak population (average of 2001 - 2003).

Comparison of the mortality level by death causes reveals differences above all between sexes. The top shares are represented by diseases of circulatory system followed by tumours, socalled civilization diseases both in males and females. However, these diseases cause $80 \%$ of deaths in females while in males it is $70 \%$. The share of deaths from circulatory diseases in females is distinctly higher as it causes $2 / 3$ of deaths. Share of deaths caused by tumours (almost a quarter of deaths) is higher in males. Almost a tenth of deaths of males are due to external causes (accidents, assaults, intentional self-damaging, complications caused by the medical care...). Such distribution of causes by sexes is connected with the biological differences between the male and female organisms but also age structure of the dead and their life style.

\subsection{Natural increase}

The rural area has always greatly contributed to the natural population increase. Religion plays an important role in the family policy in rural area above all as far as the number of children in the family, abortion or divorce are concerned. Rural females enter the marriage in a lower age than urban females. This is the reason why the population climate in issues like birth rate is more favourable in case of rural females. However, in recent years the natural increase is under the pressure of changes in economic and social developments. Precisely these transitory changes caused that the level of natural increase dropped and in some sets of prevailingly rural municipalities even the natural population decrease has been observed (Hrubý 1997). 
This fact is also confirmed by the crude rate of natural increase values when municipalities with population below 2,000 are characterized by the natural population decrease like the whole set of rural municipalities. Natural population decrease was also observed in Košice and Bratislava. However, these values are quite controlled by the population age structure. It is the reason why the indirectly standardise rate (tab. 3) better expresses the natural increase rate. It shows that precisely smaller rural municipalities (population less than thousand) boast the natural population increase. Among them are also municipalities with population between 2,000 and 5,000 with high natality rate due to the presence of the Roma ethnicity. The unfavourable population climate of cities is reflected in natural decrease of their population. The greatest natural decrease was found in municipalities with population between 10 thousand and 29 thousand; these cities are remarkable for unfavourable economic situation caused by the overall transition of the society in the 1990s, which reflects in the stagnation of the natural population increase indicators.

\begin{tabular}{|l|c|c|c|c|}
\hline & $\begin{array}{c}\text { Natural increase per } \\
\mathbf{1} \mathbf{0 0 0} \text { inhabitants (\%) }\end{array}$ & $\begin{array}{c}\text { Standardised } \\
\text { rate of natural } \\
\text { increase (\%) }\end{array}$ & $\begin{array}{c}\text { Crude } \\
\text { reproducti } \\
\text { on rate }\end{array}$ & $\begin{array}{c}\text { Net } \\
\text { reproduction } \\
\text { rate }\end{array}$ \\
\hline urban & 0,51 & - & 0,524 & 0,516 \\
\hline rural & $-0,94$ & - & 0,667 & 0,658 \\
\hline $\mathbf{0 - 1 9 9}$ & $-6,41$ & 2,30 & 0,722 & 0,712 \\
\hline $\mathbf{2 0 0 - 4 9 9}$ & $-3,60$ & 0,67 & 0,647 & 0,638 \\
\hline $\mathbf{5 0 0 - 9 9 9}$ & $-1,56$ & 1,04 & 0,681 & 0,672 \\
\hline $\mathbf{1 0 0 0 - 1 9 9 9}$ & $-0,57$ & $-0,17$ & 0,658 & 0,649 \\
\hline $\mathbf{2 0 0 0 - 4 9 9 9}$ & 0,52 & 0,85 & 0,686 & 0,676 \\
\hline $\mathbf{5 0 0 0 - 9 9 9 9}$ & 0,29 & $-0,86$ & 0,571 & 0,563 \\
\hline $\mathbf{1 0 0 0 0 - 1 9 9 9 9}$ & 0,71 & $-1,39$ & 0,532 & 0,524 \\
\hline $\mathbf{2 0 0 0 0 - 4 9 9 9 9}$ & 0,81 & $-1,17$ & 0,513 & 0,506 \\
\hline $\mathbf{5 0 0 0 0 - 9 9 9 9 9}$ & 1,04 & $-0,28$ & 0,501 & 0,494 \\
\hline $\mathbf{1 0 0 0 0 0 +}$ & $-0,42$ & $-0,40$ & 0,510 & 0,502 \\
\hline Slovakia & $-0,13$ & $\mathbf{- 0 , 1 3}$ & 0,584 & 0,576 \\
\hline
\end{tabular}

Tab 3. Natural change indicators of Slovak population (average of 2001 - 2003).

Considering the reproduction rates, both of them reach top values in the smallest municipalities and the values decrease with the increasing size of municipality. The greatest differences are observable in sets of urban and rural populations as a whole (tab. 3).

\subsection{Nuptiality}

Crude marriage rate of nuptiality increases with the increasing size of municipality. Pursuing the standardised rates, precisely the opposite is true. The top nuptiality level corresponds to the population of bigger cities (tab. 4). It is caused by the social and economic situation in rural area above all, especially concerning the housing market and family houses or their financial inaccessibility and uncertainty in the area of employment and self-assertion (Mládek, Marenčáková, Širočková 2006).

\begin{tabular}{|l|c|c|c|c|c|c|}
\hline & $\begin{array}{c}\text { Crude marriage } \\
\text { rate (\%) }\end{array}$ & $\begin{array}{c}\text { Standardised crude } \\
\text { marriage rate (\%)) }\end{array}$ & $\begin{array}{c}\text { Mean age at first } \\
\text { marriage } \\
\text { (females) }\end{array}$ & $\begin{array}{c}\text { Mean age at } \\
\text { marriage } \\
\text { (females) }\end{array}$ & $\begin{array}{c}\text { Mean age at first } \\
\text { marriage } \\
\text { (males) }\end{array}$ & $\begin{array}{c}\text { Mean age at } \\
\text { marriage } \\
\text { (males) }\end{array}$ \\
\hline urban & 4,76 & 4,63 & 25,21 & 27,00 & 27,53 & 29,94 \\
\hline rural & 4,44 & 4,55 & 23,77 & 24,74 & 26,56 & 27,74 \\
\hline $\mathbf{0 - 1 9 9}$ & 3,92 & 4,49 & 23,79 & 25,03 & 26,89 & 28,37 \\
\hline $\mathbf{2 0 0 - 4 9 9}$ & 4,20 & 4,46 & 23,85 & 24,73 & 26,75 & 27,93 \\
\hline $\mathbf{5 0 0 - 9 9 9}$ & 4,31 & 4,54 & 23,78 & 24,71 & 26,64 & 27,70 \\
\hline $\mathbf{1 0 0 0 - 1 9 9 9}$ & 4,45 & 4,53 & 23,76 & 24,74 & 26,65 & 27,77 \\
\hline $\mathbf{2 0 0 0 - 4 9 9 9}$ & 4,49 & 4,54 & 23,81 & 24,82 & 26,44 & 27,72 \\
\hline $\mathbf{5 0 0 0 - 9 9 9 9}$ & 4,56 & 4,49 & 24,32 & 25,70 & 26,97 & 28,67 \\
\hline $\mathbf{1 0 0 0 0 - 1 9 9 9 9}$ & 4,68 & 4,51 & 24,54 & 26,27 & 27,11 & 29,14 \\
\hline $\mathbf{2 0 0 0 0 - 4 9 9 9 9}$ & 4,87 & 4,71 & 24,91 & 26,55 & 27,23 & 29,41 \\
\hline $\mathbf{5 0 0 0 0 - 9 9 9 9 9}$ & 4,90 & 4,80 & 25,30 & 27,02 & 27,53 & 29,91 \\
\hline $\mathbf{1 0 0 0 0 0 +}$ & 5,00 & 4,94 & 26,43 & 28,67 & 28,58 & 31,78 \\
\hline Slovakia & 4,62 & 4,62 & 24,58 & 26,05 & 27,11 & 29,02 \\
\hline
\end{tabular}

${ }^{1)}$ Indirect standardisation

Tab 4. Nuptiality indicators of Slovak population (average of 2001 - 2003). 
The share of children born of wedlock also proves the diminishing significance of family as an authoritative unit. Alternative forms of co-existence above all cohabitations are adopted. Such forms of co-existence thrive in urban environment, while the intimate rural environment shows less understanding for alternatives to legal marriage (Benešová 2001).

Average age of brides and bridegrooms at the first marriage is higher in cities than in rural area (graph 3). The average age of brides at the first marriage is lower than 24 years and the age of bridegrooms moves around 25 years in municipalities with population below 5,000.

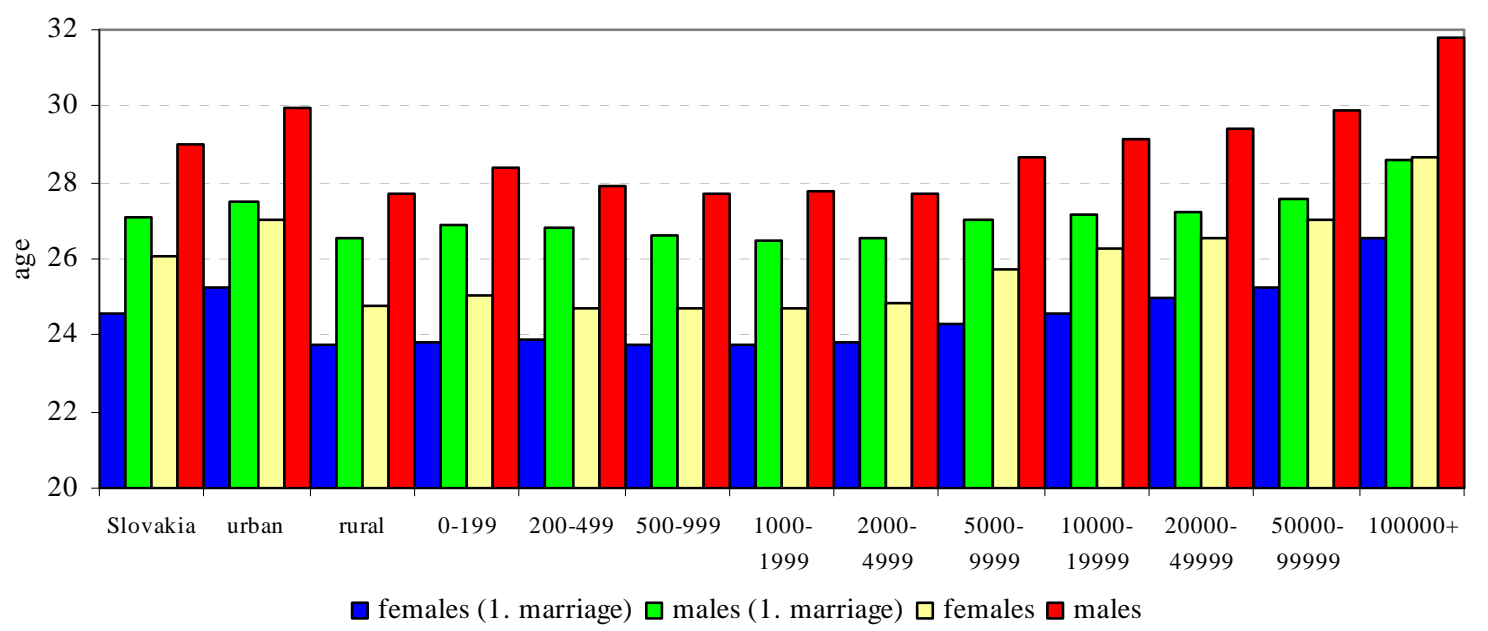

Graph 3. Mean age at marriage and at first mariage by sex - urban and rural population and communes of Slovakia (average of $2001-2003$ ).

Age at the first marriage increases with the size of municipality and that most rapidly in the set of municipalities with population over 10 thousand. The model of early nuptiality is determined by traditions, rate of religiousness and general views of these societies concerning the family and marriage issues.

The differences between individual sets of municipalities are even greater if the mean age at marriage is considered. This age of bridegrooms has already exceeded 30 in the biggest cities. In these cities, there are high shares of concluded marriages in those of higher orders concluded by couples at higher ages; in municipalities with population with population over 50,000 it is $13.3-17 \%$, and in municipalities with population below 5,000 it is $7-8 \%$ (graph 4 ).

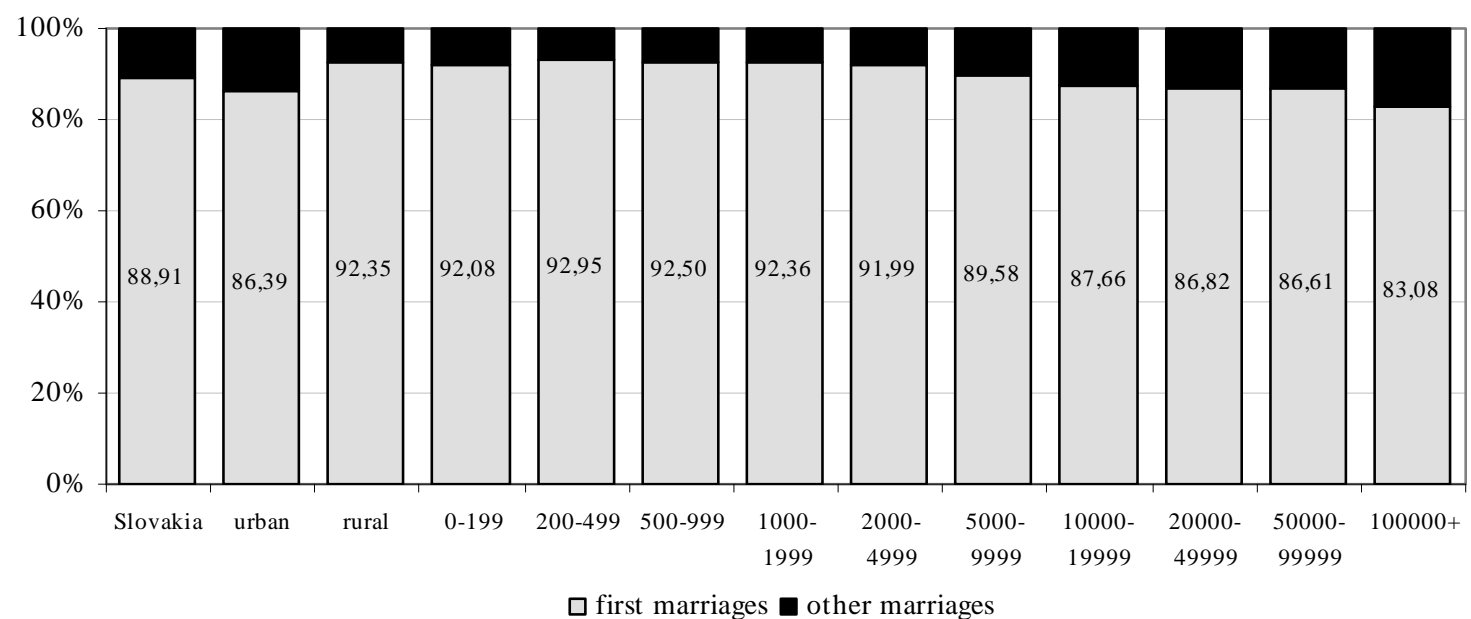

Graph 4. Share of first marriages (males) - urban and rural population and communes of Slovakia (average of 2001 2003).

\subsection{Divorce rate}

In demogeography, a strong link between the divorce level and degree of urbanization exists. Urban environment is notable for the presence of several factors that possibly reduce the stability of matrimony and family functions. Less children are born in urban families, hence the integrating function in the family is weakened, anonymity of the environment is greater and 
the possibilities to established new partner contacts reduced. High divorce rate is evidently one of manifestations of higher social mobility, fluctuation in terms of employment and frequent change of domicile. Easier acquisition of dwelling in cities has contributed to divorce rate and it is exploited mainly in rural settlements. Correlation coefficient in the analysis of the dependence of divorce rate on population number for the years 1996-2000 confirmed a distinctly positive link in case of urban settlements (0.96); this dependence in rural settlements was lower (0.8) (Mládek, Širočková 2002). Graph 5 shows, that in general, with the increasing size of municipality, the gross rate of divorce increases as well. The top values of divorce level as well as those of divorce index are observed in cities with population between 20,000 and 50,000. Divorce index value though does not only reveal the increasing divorce rate but also the decreasing nuptiality rate. Above all in municipalities with population over 5,000 , the value of this indicator dramatically increases.

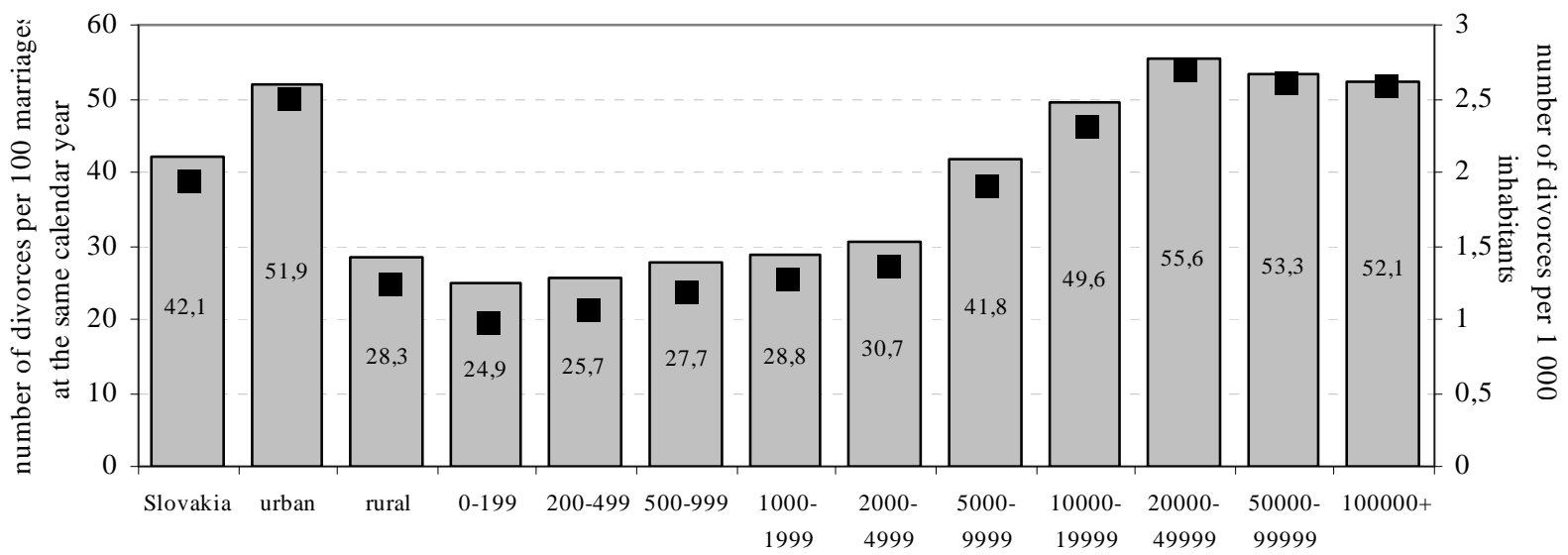

Graph 5. Divorce index and crude divorce rate - urban and rural population and communes of Slovakia (average of 2001 - 2003).

Number of children in family is an important factor determining the divorce level. Matrimonies with more children (three and more dependent children) are characterized by a higher stability (Michálek 2000). Such group of divorces represents the lowest share in all size sets of municipalities. Share of divorcing marriages with two and more children is higher in smaller municipalities with a multiple family model; in cities with population over 20,000 the share of divorces of childless couples increases. Divorce of marriages with two children dominates in all sets, as this is the model that prevails in the Slovak society.

The most frequent cause and the one leading to breach of marriage which outlasts for quite a long time now is the deep disparity in opinion, characters, interests, etc. of partners. Nature of this cause is ambiguous and universal. Alcoholism and adultery are high in the category of males while no fault was specified for $20-25 \%$ of females (tab. 5). These facts suggest that males more often disturb the stability of their marriages by behaviour what indicates at the same time that females apply for divorce more frequently (Michálek 2000).

\begin{tabular}{|l|c|c|c|c|c|c|c|c|}
\hline \multirow{2}{*}{} & \multicolumn{9}{|c|}{ Share of divorces by cause (\%) } \\
\cline { 2 - 10 } & $\mathbf{2}$ & $\mathbf{3}$ & $\mathbf{4}$ & $\mathbf{6}$ & $\mathbf{3}$ & $\mathbf{6}$ & $\mathbf{9}$ & $\mathbf{0}$ \\
\cline { 2 - 10 } & 9,20 & 10,25 & 7,43 & 59,58 & 5,15 & 59,58 & 8,34 & 18,75 \\
\hline urban & 13,98 & 10,41 & 8,75 & 51,00 & 7,11 & 51,00 & 9,06 & 22,91 \\
\hline rural & 13,24 & 12,50 & 11,77 & 50,74 & 8,82 & 50,74 & 11,03 & 21,32 \\
\hline $\mathbf{2 0 0 - 4 9 9}$ & 17,28 & 9,65 & 8,75 & 46,35 & 8,87 & 46,35 & 7,86 & 24,58 \\
\hline $\mathbf{5 0 0 - 9 9 9}$ & 13,39 & 11,68 & 8,98 & 48,65 & 6,22 & 48,65 & 9,13 & 25,53 \\
\hline $\mathbf{1 0 0 0 - 1 9 9 9}$ & 14,32 & 10,60 & 8,86 & 50,96 & 7,45 & 50,96 & 9,02 & 22,88 \\
\hline $\mathbf{2 0 0 0 - 4 9 9 9}$ & 13,40 & 9,64 & 8,60 & 54,00 & 6,64 & 54,00 & 8,63 & 21,71 \\
\hline $\mathbf{5 0 0 0 - 9 9 9 9}$ & 13,53 & 11,16 & 8,65 & 50,12 & 6,69 & 50,12 & 11,39 & 23,57 \\
\hline $\mathbf{1 0 0 0 0 - 1 9 9 9 9}$ & 10,98 & 10,88 & 8,35 & 54,98 & 6,36 & 54,98 & 8,42 & 21,96 \\
\hline $\mathbf{2 0 0 0 0 - 4 9 9 9 9}$ & 10,42 & 11,42 & 8,49 & 55,12 & 6,23 & 55,12 & 7,52 & 22,10 \\
\hline $\mathbf{5 0 0 0 0 - 9 9 9 9 9}$ & 8,44 & 10,54 & 8,00 & 59,40 & 4,61 & 59,40 & 7,55 & 19,01 \\
\hline $\mathbf{1 0 0 0 0 0 +}$ & 5,04 & 7,55 & 4,21 & 72,80 & 2,86 & 72,80 & 9,25 & 9,34 \\
\hline Slovakia & 10,54 & 10,29 & 7,80 & 57,18 & 5,70 & 57,18 & 8,54 & 19,91 \\
\hline
\end{tabular}

Causes of divorce: 2/Alcoholism, 3/Adultery, 4/Lack of interest in the family, 6/Personality differences, 9/Other causes, 0/Not specified

Tab 5. Share of divorces by causes - urban and rural population of Slovakia (average of 2001 - 2003). 


\subsection{Abortion}

High crude abortion rate was the most negative feature of the demographic development in Slovakia by the end of the 1980s. The cause was the easy access to induced abortion guaranteed by the law and supported by the practice, its social approval, and overall social climate that suppressed the personal responsibility of an individual, a long-term lack of modern contraceptives. Induced abortion was often referred to as an ex-post contraception. The decrease of induced abortion rate may be perhaps connected with a distinct spread of quality contraceptive methods, introduction of sexual education at schools, better information of the public, etc. (Cuperová, Filadelfiová 2000, Mládek, Marenčáková, Širočková 2006).

\begin{tabular}{|c|c|c|c|c|c|c|c|}
\hline & $\begin{array}{c}\text { Crude } \\
\text { abortion } \\
\text { rate (\%o) } \\
\end{array}$ & $\begin{array}{c}\text { Crude induced } \\
\text { abortion rate } \\
(\%)\end{array}$ & $\begin{array}{c}\text { Standardised crude } \\
\text { induced abortion } \\
\text { rate }(\% 0)^{1)}\end{array}$ & $\begin{array}{l}\text { General } \\
\text { abortion } \\
\text { rate (\%o) } \\
\end{array}$ & $\begin{array}{c}\text { General induced } \\
\text { abortion } \\
\text { rate (\%o) }\end{array}$ & $\begin{array}{l}\text { Abortion } \\
\text { index } \\
(\%) \\
\end{array}$ & $\begin{array}{c}\text { Mean age of } \\
\text { woman at } \\
\text { abortion }\end{array}$ \\
\hline urban & 4,56 & 3,66 & 3,50 & 15,93 & 12,77 & 52,02 & 29,30 \\
\hline rural & 3,50 & 2,62 & 2,79 & 14,22 & 10,63 & 33,47 & 28,91 \\
\hline 0-199 & 3,52 & 2,61 & 3,28 & 17,07 & 12,65 & 36,89 & 29,45 \\
\hline $200-499$ & 3,27 & 2,46 & 2,74 & 13,95 & 10,46 & 33,90 & 28,91 \\
\hline $500-999$ & 3,37 & 2,47 & 2,70 & 14,02 & 10,28 & 32,38 & 28,86 \\
\hline 1000-1999 & 3,45 & 2,58 & 2,72 & 13,85 & 10,35 & 33,12 & 29,00 \\
\hline 2000-4999 & 3,80 & 2,87 & 2,97 & 14,99 & 11,31 & 34,54 & 28,81 \\
\hline $5000-9999$ & 4,17 & 3,24 & 3,18 & 15,23 & 11,83 & 43,85 & 29,18 \\
\hline $10000-19999$ & 4,75 & 3,66 & 3,47 & 16,63 & 12,81 & 52,17 & 28,95 \\
\hline $20000-49999$ & 4,72 & 3,78 & 3,54 & 16,22 & 12,98 & 53,83 & 29,23 \\
\hline 50000-99999 & 4,21 & 3,33 & 3,17 & 14,48 & 11,46 & 50,36 & 29,59 \\
\hline $100000+$ & 4,76 & 4,05 & 3,92 & 16,65 & 14,14 & 56,99 & 29,43 \\
\hline Slovakia & 4,10 & 3,20 & 3,20 & 15,24 & 11,91 & 43,04 & 29,16 \\
\hline
\end{tabular}

${ }^{1)}$ Indirect standardisation

Tab 6. Abortion indicators of Slovak population (average of $2001-2003$ ).

Crude abortion and induced abortion rates in the rural area are lower than in the cities and increase with the increasing size of the municipality (tab. 6). This fact was confirmed in indirectly standardised rates; the values increased in smaller municipalities, and that most distinctly in municipalities with lower population number. Young women in cities use more often contraceptives regulating the fertility and the abortion as a brutal method is less opted for. The values of the crude induced abortion rate are overestimated; hence those of the standardised rate are lower.

The index of abortion rate does not only express the drop of the abortion rate but even more clearly the drop of fertility and natality. In the cities with population over 10 thousand more than 50 abortions correspond to 100 live births; the lowest value was found in municipalities with population between 500 and 999 where there is a high natality rate caused by the presence of the Roma minority. Abortion is often socially unacceptable in the rural environment with its informal control by the community and a high level of religiousness, as the low values of this indicator reflect.

\subsection{Migration mobility}

Rural municipalities are characterized by the migration gain at the cost of cities. It is precisely the reverse process compared to the one that took place in the 1950s to 1980s in this country (tab. 7). Municipalities with population below 5 thousand gained by migration (with the exception of the smallest ones with population below 200$)$; the greatest migration gain $(4.5 \%$ ) was observed in municipalities with population from 1 thousand to 20 thousand. A very important factor though is their geographical position, because municipalities situated near cities loosing by migration gain at their cost. Migration losses of cities are also due to the increased number of those who move to suburban municipalities and to the drop of immigrants. Migration gain of small municipalities is to certain extent limited by a relatively complicated search for a new dwelling what makes it difficult to emigrate.

Factors like the reduced construction of dwellings after 1990, high prices of dwelling and often unsettled ownership rights are in way to formation and functioning of a housing market and constitute a barrier to migration. 


\begin{tabular}{|l|l|l|l|}
\hline & $\begin{array}{l}\text { Crude rate } \\
\text { of net } \\
\text { migration } \\
(\%)\end{array}$ & $\begin{array}{l}\text { Migration } \\
\text { efficiency }\end{array}$ & $\begin{array}{l}\text { Mobility } \\
\text { index } \\
(\%)\end{array}$ \\
\hline urban & $-2,69$ & $-0,18$ & 15,32 \\
\hline rural & 3,89 & 0,21 & 18,64 \\
\hline $\mathbf{0 - 1 9 9}$ & $-0,24$ & $-0,01$ & 37,49 \\
\hline $\mathbf{2 0 0 - 4 9 9}$ & 3,09 & 0,10 & 31,99 \\
\hline $\mathbf{5 0 0 - 9 9 9}$ & 4,12 & 0,14 & 29,98 \\
\hline $\begin{array}{l}\mathbf{1 0 0 0 -} \\
\mathbf{1 9 9 9}\end{array}$ & 4,49 & 0,16 & 27,52 \\
\hline $\mathbf{2 0 0 0 -}$ & & 0,13 & 25,45 \\
\hline $\mathbf{4 9 9 9}$ & 3,27 & $-0,02$ & 27,87 \\
\hline $\begin{array}{l}\mathbf{5 0 0 0 -} \\
\mathbf{9 9 9 9}\end{array}$ & $-0,42$ & $-0,10$ & 27,49 \\
\hline $\begin{array}{l}\mathbf{1 0 0 0 0 -} \\
\mathbf{1 9 9 9 9}\end{array}$ & $-2,62$ & $-0,13$ & 25,02 \\
\hline $\begin{array}{l}\mathbf{2 0 0 0 0 -} \\
\mathbf{4 9 9 9 9}\end{array}$ & $-3,15$ & $-0,19$ & 22,82 \\
\hline $\begin{array}{l}\mathbf{5 0 0 0 0 -} \\
\mathbf{9 9 9 9 9}\end{array}$ & $-4,32$ & $-0,09$ & 19,42 \\
\hline $\mathbf{1 0 0 0 0 0 +}$ & $-1,69$ & 0,31 & 0,65 \\
\hline Slovakia & 0,21 & \\
\hline
\end{tabular}

Tab 7. Migration indicators of Slovak population (average of $2001-2003$ ).

The prevailing part of the rural area in Slovakia looses population. Suburban and some other rural areas that result attractive for older population constitute an exception. Younger age groups still prefer big urban centres while families tend to seek living in hinterland of cities (Mládek, a kol. 2006).

\subsection{Overall population change}

Due to the migration gain, an overall increase was observed in rural municipalities with population below 5,000; municipalities with population below 500 are characterized by an overall migration loss while the natural decrease caused by unfavourable age structure (tab. 8) represents a high share. Municipalities with population below 200 experienced a negative balance in both indicators; they are municipalities located in the peripheries with low population density, lower income, high expenses for education and health service connected with missing infrastructure and transport networks.

\begin{tabular}{|l|c|c|c|}
\hline & $\begin{array}{c}\text { Natural increase } \\
\text { per 1 000 } \\
\text { inhabitants (\%o) }\end{array}$ & $\begin{array}{c}\text { Net migration } \\
\text { per 1 000 } \\
\text { inhabitents(\%) }\end{array}$ & $\begin{array}{c}\text { Total population } \\
\text { increase per 1 000 } \\
\text { inhabitants (\%o) }\end{array}$ \\
\hline urban & 0,51 & $-2,69$ & $-2,18$ \\
\hline rural & $-0,94$ & 3,89 & 2,95 \\
\hline $\mathbf{0 - 1 9 9}$ & $-6,41$ & $-0,24$ & $-6,66$ \\
\hline $\mathbf{2 0 0 - 4 9 9}$ & $-3,60$ & 3,09 & $-0,50$ \\
\hline $\mathbf{5 0 0 - 9 9 9}$ & $-1,56$ & 4,12 & 2,56 \\
\hline $\mathbf{1 0 0 0 - 1 9 9 9}$ & $-0,57$ & 4,49 & 3,92 \\
\hline $\mathbf{2 0 0 0 - 4 9 9 9}$ & 0,52 & 3,27 & 3,79 \\
\hline $\mathbf{5 0 0 0 - 9 9 9 9}$ & 0,29 & $-0,42$ & $-0,13$ \\
\hline $\mathbf{1 0 0 0 0 - 1 9 9 9 9}$ & 0,71 & $-2,62$ & $-1,91$ \\
\hline $\mathbf{2 0 0 0 0 - 4 9 9 9 9}$ & 0,81 & $-3,15$ & $-2,34$ \\
\hline $\mathbf{5 0 0 0 0 - 9 9 9 9 9}$ & 1,04 & $-4,32$ & $-3,27$ \\
\hline $\mathbf{1 0 0 0 0 0 +}$ & $-0,42$ & $-1,69$ & $-2,10$ \\
\hline Slovakia & $-0,13$ & 0,21 & 0,08 \\
\hline
\end{tabular}

Tab 8. Total population change indicators of Slovak population (average of 2001 - 2003). 
Bigger rural municipalities enjoy migration gain and the positive balance of the overall population change (graph 6). They are prevailingly the municipalities located in hinterland of cities, which become attractive for urban population. In municipalities with population over 5 thousand, migration loss is the decisive factor due to unfavourable situation in housing market and also because of above-mentioned suburbanising trends next to bigger cities.

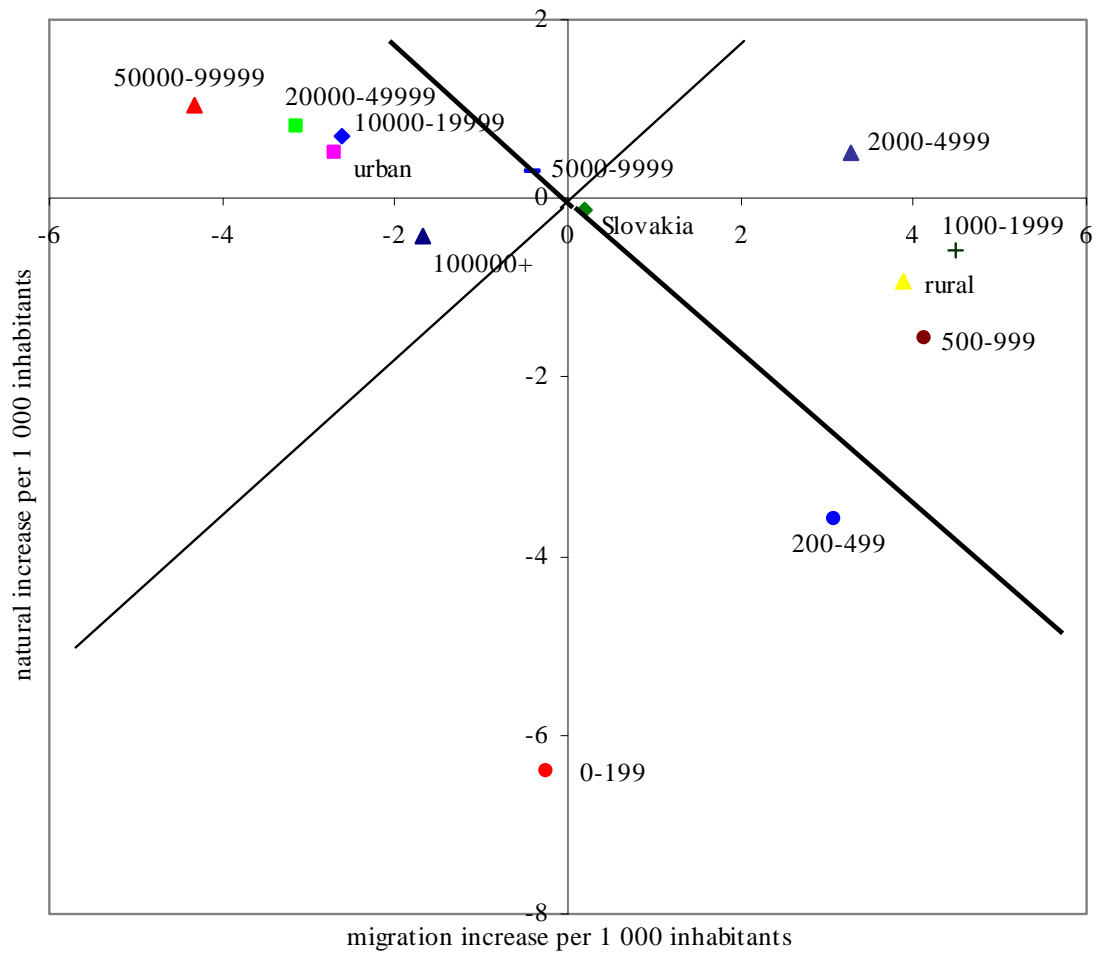

Graph 6. Types of total population change - communes of Slovakia (average of 2001 - 2003).

\section{Different population structures in urban and rural settlements}

\subsection{Population structure by age and sex}

Females slightly prevail in the long-term population development in Slovakia like in the majority of developed countries. One of the causes is attributable to the historical development and phenomena like masculinity of the newborn, excessive death rate of males and international migration.

\begin{tabular}{|c|c|c|c|c|c|c|}
\hline \multirow{2}{*}{ Age } & \multicolumn{2}{|c|}{ Slovakia } & \multicolumn{2}{c|}{ Urban population } & \multicolumn{2}{c|}{ Rural population } \\
\cline { 2 - 7 } & $\begin{array}{c}\text { Share of } \\
\text { females (\%) }\end{array}$ & $\begin{array}{c}\text { Femininity } \\
\text { index (\%) }\end{array}$ & $\begin{array}{c}\text { Share of } \\
\text { females (\%) }\end{array}$ & $\begin{array}{c}\text { Femininity } \\
\text { index (\%) }\end{array}$ & $\begin{array}{c}\text { Share of } \\
\text { females (\%) }\end{array}$ & $\begin{array}{c}\text { Femininity } \\
\text { index (\%) }\end{array}$ \\
\hline $\mathbf{0 - 4}$ & 48,72 & 950,24 & 48,76 & 951,52 & 48,69 & 948,97 \\
\hline $\mathbf{5 - 9}$ & 48,81 & 953,41 & 48,88 & 956,31 & 48,72 & 950,17 \\
\hline $\mathbf{1 0 - 1 4}$ & 48,93 & 958,12 & 49,01 & 961,10 & 48,83 & 954,15 \\
\hline $\mathbf{1 5 - 1 9}$ & 48,90 & 957,00 & 48,85 & 955,13 & 48,97 & 959,64 \\
\hline $\mathbf{2 0 - 2 4}$ & 49,02 & 961,47 & 49,03 & 961,79 & 49,01 & 961,04 \\
\hline $\mathbf{2 5 - 2 9}$ & 49,18 & 967,82 & 49,92 & 996,97 & 48,23 & 931,77 \\
\hline $\mathbf{3 0 - 3 4}$ & 49,47 & 979,12 & 51,23 & 1050,24 & 47,22 & 894,78 \\
\hline $\mathbf{3 5 - 3 9}$ & 49,76 & 990,30 & 51,92 & 1079,73 & 46,70 & 876,10 \\
\hline $\mathbf{4 0 - 4 4}$ & 49,80 & 992,20 & 51,89 & 1078,72 & 46,64 & 874,12 \\
\hline $\mathbf{4 5 - 4 9}$ & 50,61 & 1024,55 & 52,09 & 1087,42 & 48,28 & 933,50 \\
\hline $\mathbf{5 0 - 5 4}$ & 51,60 & 1066,11 & 52,51 & 1105,55 & 50,29 & 1011,64 \\
\hline $\mathbf{5 5 - 5 9}$ & 54,00 & 1174,13 & 54,54 & 1199,54 & 53,34 & 1143,02 \\
\hline $\mathbf{6 0 - 6 4}$ & 55,99 & 1272,33 & 56,06 & 1276,07 & 55,91 & 1268,34 \\
\hline $\mathbf{6 5 - 6 9}$ & 58,24 & 1394,53 & 57,78 & 1368,81 & 58,69 & 1420,87 \\
\hline $\mathbf{7 0 - 7 4}$ & 61,22 & 1578,39 & 60,73 & 1546,49 & 61,66 & 1608,55 \\
\hline $\mathbf{7 5 - 7 9}$ & 64,50 & 1816,97 & 64,05 & 1781,73 & 64,90 & 1848,84 \\
\hline $\mathbf{8 0 - 8 4}$ & 66,51 & 1985,62 & 65,72 & 1917,55 & 67,19 & 2047,66 \\
\hline $\mathbf{8 5 +}$ & 70,09 & 2343,62 & 70,26 & 2362,03 & 69,95 & 2328,20 \\
\hline Total & 51,44 & 1059,13 & 51,90 & 1079 & 50,84 & 1034,17 \\
\hline
\end{tabular}

Tab 9. Sex structure of urban and rural population of Slovakia (2001) 
Pursuing the 2001 Population Census, the share of females in Slovakia was 51.44\%; the feminity index reached the value of 1059 (tab. 9). The share of females was higher than $50 \%$ starting by the age category of $45-49$ years $(50.61 \%)$. The two indicators reached the highest value in the top age category of 85 years and over.

Comparison of sex and age structures of urban and rural population reveals that the share of females is higher in the cities already from the age category of 30-34 years. In rural population, females start to prevail from the age category of 50-54 years (graph 7). These differences in sex distribution are caused mainly by migration of females in productive age to cities as proved by the low values of the feminity index in rural population in age categories of its economic activity. It drops below 900 in the age category of 30-44.

The femininity index in urban population is 1,079 , probably due to above-mentioned immigration of females motivated by work. The lower value in rural population may be attributed to the concentration of younger population in rural area (higher dynamics of rural population) where males dominate.

Evaluation of age population structures is often oriented to the description of representation by individual age categories or change in their representation. Precisely these changes in population age structure are referred to as the ageing and are considered one of general laws controlling the development of the majority of population structures on the level of regions of different scales.

urban population

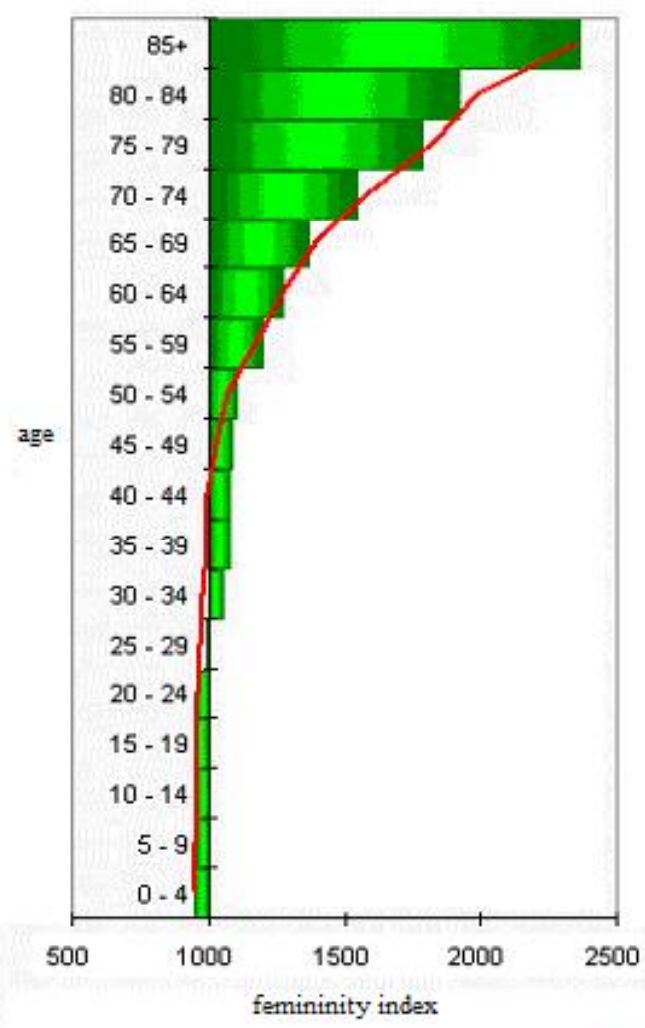

rural population

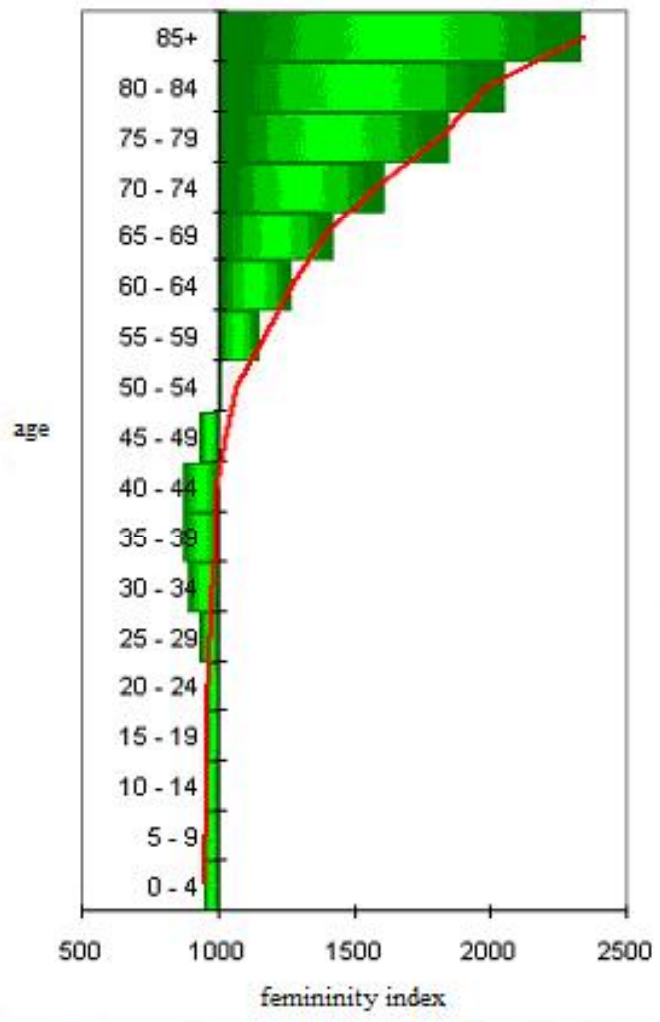

Graph 7. Sex structure of urban and rural population of Slovakia (2001).

The comparison of urban and rural settlement sets suggests a more intensive ageing of rural population as confirmed by higher values of indicators like mean age, ageing index, dependency index and ageing rate (tab. 9). This process is connected with long-term migration trend of rural population to the cities in the consequence of job distribution in almost all sectors where the young population finds employment. In 2001, population in productive age represented as much as $65.4 \%$ of total population in urban settlements compared to the rural area where it was $59.5 \%$. All higher age categories are more abundantly represented in rural settlements. Such distribution of population may be even accentuated in future. Quality dwelling 
and the environment in rural area may attract urban population in the retirement age. Such type of migration is presumed for the suburban areas above all. As far as the share of the children component of age structure is concerned, rural settlements boast younger population In 1991, cities still had a high share of children population $(26,5 \%)$, even higher than the rural area $(22,8 \%)$. However, cities were subject to a bottom-up ageing during the following ten years.

Similar conclusions are drawn from the assessment of population age structure by size groups of settlements. It seems that the bigger the settlement the younger its population. Some indicators are quite clear about that: the share of post-productive population group, the share of the 80-year old and older, the mean age, the ageing index, and the ageing rate drop with the increasing size of a settlement, (tab. 10). Of course, there are also less definite indicators as well. The share of the children component increases until the categories of settlement with population 5,000 and then it decreases. The decisive significance is also attributed to representation of population in productive age. This share is extremely high in bigger settlements (64-66\%) and its effects on shares of other age categories can be quiet strong. Age structure of two groups of settlements, the biggest and the smallest ones is special. In the group of settlements with population below 200, the category of productive population is extremely small because it emigrated for lack of jobs. Along with this category, the children component characterized by a 15 percent point lower share than the national average in this group of settlements, leaves too. Population in post-productive age accumulates in such settlements; their share is by $11.5 \%$ higher than the national average. The biggest cities possess the lowest share of population at a child's age (by $3 \%$ less than the national average) what hints at a bottom-up ageing.
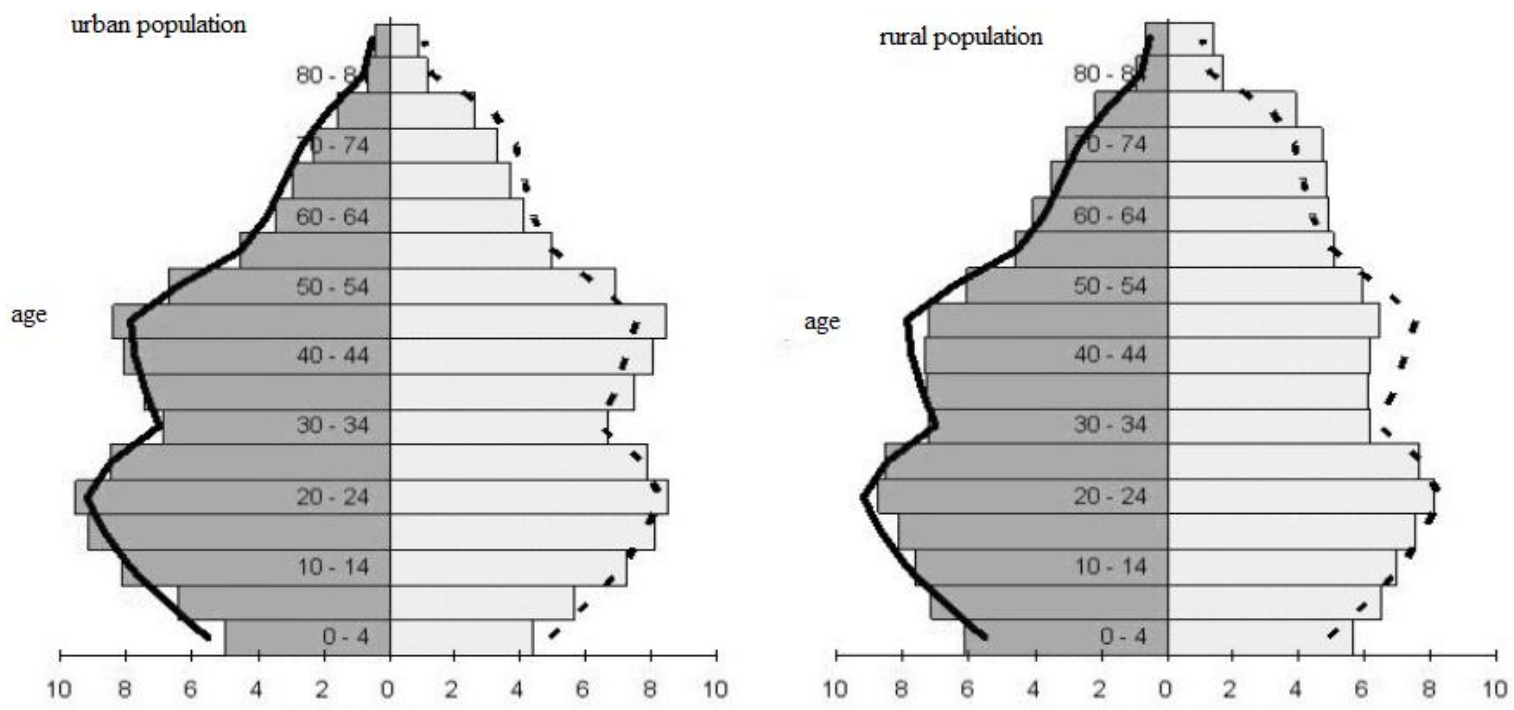

Graph 8. Age structure of urban and rural population of Slovakia (2001).

\begin{tabular}{|c|c|c|c|c|c|c|c|c|c|}
\hline & \multicolumn{5}{|c|}{ Share of age cathegory in total population (v \%) } & \multirow{2}{*}{$\begin{array}{l}\text { Mean } \\
\text { age }\end{array}$} & \multirow{2}{*}{$\begin{array}{l}\text { Ageing } \\
\text { index }\end{array}$} & \multirow{2}{*}{$\begin{array}{l}\text { Age } \\
\text { index }\end{array}$} & \multirow{2}{*}{$\begin{array}{c}\text { Billeter } \\
\text { s index }\end{array}$} \\
\hline & $0-14$ & $\begin{array}{c}15 \text { - } 54 \text { females } \\
15 \text { - } 55 \text { malesi }\end{array}$ & $\begin{array}{c}55+\text { females } \\
60+\text { males }\end{array}$ & $\begin{array}{l}65 \text { and } \\
\text { over }\end{array}$ & $\begin{array}{l}80 \text { and } \\
\text { over }\end{array}$ & & & & \\
\hline urban & 18,3 & 65,4 & 16,2 & 9,9 & 1,6 & 35,7 & 88,6 & 72,6 & $-12,2$ \\
\hline rural & 20 & 59,5 & 20,5 & 13,5 & 2,3 & 36,6 & 102,9 & 69,4 & $-17,2$ \\
\hline $0-199$ & 17 & 53,4 & 29,6 & 21,1 & 4,2 & 41,2 & 174,3 & 44,7 & $-46,6$ \\
\hline $200-499$ & 18,9 & 57,2 & 23,8 & 14,9 & 3 & 38,2 & 126 & 59,1 & $-26,7$ \\
\hline $500-999$ & 19,8 & 59 & 21,2 & 14,1 & 2,5 & 36,9 & 107,4 & 67,2 & -19 \\
\hline 1000 - 1999 & 19,9 & 59,9 & 20,2 & 13,1 & 2,2 & 36,4 & 101,6 & 69,6 & $-16,8$ \\
\hline $2000-4999$ & 20,9 & 60,7 & 18,4 & 11,8 & 1,9 & 35,4 & 88 & 78,8 & $-10,7$ \\
\hline 5000 - 9999 & 20 & 63,6 & 16,4 & 10,2 & 1,7 & 35,1 & 82,2 & 80,5 & $-8,7$ \\
\hline 10000 - 19999 & 19,5 & 65,4 & 15,1 & 9 & 1,4 & 34,7 & 77,4 & 82,5 & $-8,6$ \\
\hline 20000 - 49999 & 18,7 & 66 & 15,3 & 9 & 1,4 & 35,2 & 81,8 & 77,6 & $-9,6$ \\
\hline 50000 - 99999 & 18,1 & 66 & 15,9 & 9,6 & 1,5 & 35,6 & 88,3 & 72,6 & -12 \\
\hline $100000+$ & 15,9 & 65,3 & 18,9 & 11,6 & 1,9 & 37,7 & 118,8 & 54,7 & $-23,8$ \\
\hline Slovakia & 19 & 62,8 & 18,2 & 11,5 & 1,9 & 36,1 & 95,2 & 71,1 & $-14,3$ \\
\hline
\end{tabular}

Tab 10. Age structure indicators of urban and rural population of Slovakia (2001). 


\subsection{Ethnic structure}

Pursuing the 2001 Population Census, $85.8 \%$ of population in Slovakia are Slovaks. Slovak population prevails in the whole territory of the country with the exception of the belt running along the southern boundary of Slovakia where in some municipalities population adhering to the Hungarian ethnicity prevails. Tab. 11 and graph 12 shows that Slovak population distinctly dominates (more than $80 \%$ ) both in cities and villages. Its share in the rural area though is reduced by a high percentage of population appurtenant to other ethnicities, which are spatially bound precisely to the rural area.

\begin{tabular}{|l|c|c|c|c|c|}
\hline & \multicolumn{5}{|c|}{ Share of population by ethnicity (v \%) } \\
\cline { 2 - 6 } & Slovak & Hungarian & Roma & Czech & $\begin{array}{c}\text { Ruthenian and } \\
\text { Ukrainian }\end{array}$ \\
\hline urban & 88,48 & 6,64 & 1,28 & 1,14 & 0,60 \\
\hline rural & 82,83 & 13,57 & 2,18 & 0,44 & 0,70 \\
\hline $\mathbf{0}$ - 199 & 81,10 & 9,20 & 1,40 & 0,50 & 6,80 \\
\hline $\mathbf{2 0 0}-\mathbf{4 9 9}$ & 80,90 & 13,90 & 1,70 & 0,40 & 2,20 \\
\hline $\mathbf{5 0 0}-\mathbf{9 9 9}$ & 82,10 & 13,90 & 2,00 & 0,40 & 0,70 \\
\hline $\mathbf{1 0 0 0}$ - 1999 & 83,00 & 13,50 & 2,10 & 0,40 & 0,20 \\
\hline $\mathbf{2 0 0 0}-\mathbf{4 9 9 9}$ & 84,30 & 11,40 & 2,80 & 0,50 & 0,20 \\
\hline $\mathbf{5 0 0 0}-\mathbf{9 9 9 9}$ & 79,40 & 16,20 & 1,70 & 0,70 & 0,90 \\
\hline $\mathbf{1 0 0 0 0}-\mathbf{1 9 9 9 9}$ & 84,60 & 10,40 & 1,70 & 1,00 & 0,70 \\
\hline $\mathbf{2 0 0 0 0}-\mathbf{4 9 9 9 9}$ & 86,20 & 8,90 & 1,60 & 0,90 & 0,80 \\
\hline $\mathbf{5 0 0 0 0}-\mathbf{9 9 9 9 9}$ & 95,40 & 0,50 & 0,60 & 1,30 & 0,40 \\
\hline $\mathbf{1 0 0 0 0 0}+$ & 90,60 & 3,80 & 0,80 & 1,60 & 0,50 \\
\hline Slovakia & 85,80 & 9,70 & 1,70 & 0,80 & 0,70 \\
\hline
\end{tabular}

Tab 11. Ethnic structure indicators of urban and rural population of Slovakia (2001).

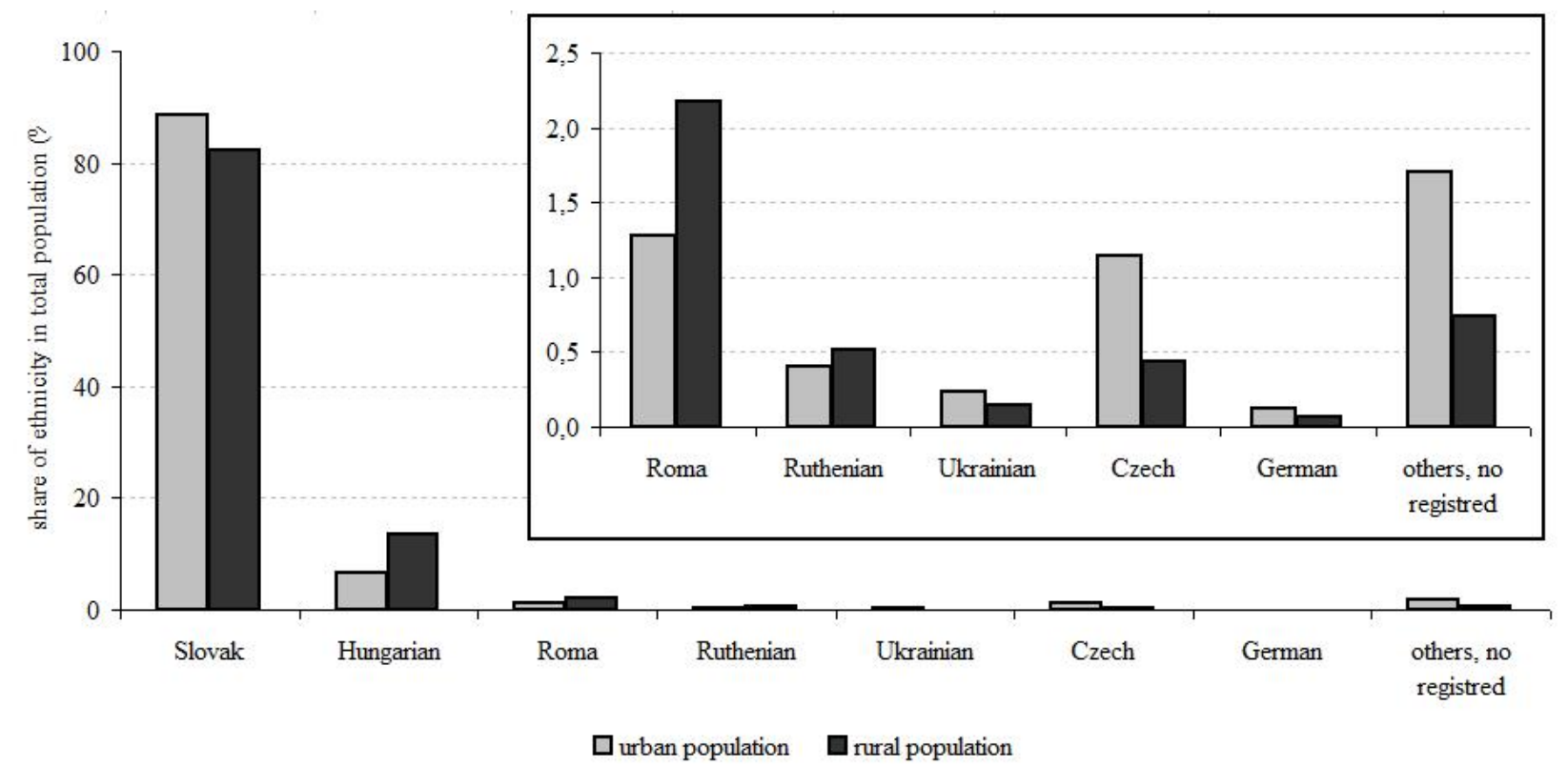

Graph 9. Ethnic structure of urban and rural population of Slovakia (2001).

As much as $70 \%$ of municipalities in Slovakia is inhabited by more than $90 \%$ of Slovaks and in more than $80 \%$ municipalities this ethnicity forms a majority (Mládek, a kol. 2006). Slovak population reached the highest share $(95.4 \%)$ in the size category of municipalities with population from 50 thousand to 100 thousand and the lowest in the size category with population from 5 thousand to 10 thousand and in those with population 200-499 (80.9\%). In both cases there is a high concentration of Hungarian ethnicity in these size categories and in the smallest one it is also accompanied by the Roma, Ruthenian and/or the Ukrainian ethnicities (tab. 11).

The second most populous ethnicity in Slovakia is the Hungarian with $9.7 \%$ of the total population. This ethnicity concentrates along the boundary with Hungary. The Hungarian ethnicity amounts to more than a double in rural area compared to urban population. This phenomenon is caused above all by concentration of Hungarians into the agriculturally most 
developed areas of Slovakia with the lowest rate of urbanization and where farming enjoys a historic tradition. Hungarians are also abundantly represented in municipalities with population $200-10,000$ and it is highest (16.2\%) in municipalities with population between 5 thousand and 10 thousand. The lowest share of Hungarian ethnicity was found in cities with population over 50,00 meanwhile the cities with population over 20,000 display shares lower than the national average.

The third most populous ethnicity that of Romas in Slovakia officially represents $1.7 \%$ of total population but the estimated real number is four-times higher. Roma population is distributed in rural municipalities and their share in rural and urban populations is $2.18 \%$ and $1.28 \%$ respectively. The highest share (more than $2 \%$ ). of Romas is in municipalities with population from 500 to 5 thousand and the lowest share of Romas (less than 1\%) lives in big cities with population exceeding 50 thousand.

The share of the Czech ethnicity in the ethnic structure of Slovakia amounts to 0.8 percent. In urban and rural population the shares of the Czech ethnicity amount to $1.14 \%$ and only $0.44 \%$ respectively. The higher share of Czechs in cities is connected with migration in the 1920s and the 30s (establishment of the Czechoslovak Republic) when they arrived to take over positions in the Slovak administration, schools, police, etc. and also in the 1950s when qualified Czech workers migrated to Slovakia to enter the newly founded industrial plants and factories (Dubcová, a kol. 2006).

The Ruthenian and Ukrainian populations are often quoted together as the definition of these ethnicities is subject to discussion. Their share in population of Slovakia is only $0.7 \%$. Assessing the two ethnicities separately it becomes obvious that the Ruthenian population is linked to the rural area $(0.52 \%$ of population), while Ukrainians prevail in cities $(0.24 \%$ of urban population). As far as location of these ethnicities is concerned by size categories of municipalities their share is significant $(6.8 \%)$ in the smallest settlements with population below 200. Their share is high above the national average $(2.2 \%)$ in the category with population from 200 to 499. An increased share was also found in municipalities with population from 5 thousand to 50 thousand. The lowest share $(0.2 \%)$ was observed in municipalities with population from 1 thousand to 5 thousand.

The German ethnicity amounts to only $0.1 \%$ of total population in Slovakia. The presence of the German ethnicity is linked to the cities where they developed industry and trade in the past (DUBCOVÁ, A KOL. 2006). In 2001, their share in cities represented $0.12 \%$.

\subsection{Religious structure}

In spite of historic events in the last decades, Slovakia is remarkable for a comparatively high degree of religiousness. According to the 2001 Population Census, $13 \%$ of population declared themselves atheists and as the share of unspecified religion was $3 \%$, the rate of religiousness represented $84 \%$ (tab. 12, graph 10 ).

\begin{tabular}{|c|c|c|c|c|c|c|c|}
\hline & \multicolumn{3}{|c|}{ Share in total population (v \%) } & \multicolumn{4}{|c|}{ Share in believers (v \%) } \\
\hline & believers & $\begin{array}{c}\text { no } \\
\text { religion }\end{array}$ & $\begin{array}{c}\text { not } \\
\text { specified }\end{array}$ & $\begin{array}{c}\text { Roman } \\
\text { Catholic }\end{array}$ & $\begin{array}{c}\text { Greek } \\
\text { Catholic }\end{array}$ & $\begin{array}{c}\text { Evangelical } \\
\text { A. c. }\end{array}$ & $\begin{array}{l}\text { Reformed } \\
\text { Christian }\end{array}$ \\
\hline urban & 77,0 & 19,1 & 3,9 & 82,4 & 4,4 & 8,5 & 1,7 \\
\hline rural & 93,1 & 5,0 & 1,8 & 81,6 & 5,3 & 8,0 & 3,2 \\
\hline 0 - 199 & 93,6 & 4,6 & 1,8 & 49,9 & 21,3 & 16,2 & 4,1 \\
\hline $200-499$ & 93,9 & 4,4 & 1,7 & 66,9 & 12,8 & 12,6 & 4,4 \\
\hline $500-999$ & 93,8 & 4,5 & 1,7 & 76,2 & 6,7 & 10,3 & 4,2 \\
\hline $1000-1999$ & 93,1 & 5,1 & 1,8 & 85,2 & 3,9 & 6,8 & 3,0 \\
\hline $2000-4999$ & 91,1 & 6,7 & 2,1 & 88,5 & 2,2 & 6,0 & 2,1 \\
\hline 5000 - 9999 & 86,3 & 11,0 & 2,7 & 82,9 & 3,7 & 7,3 & 3,7 \\
\hline 10000 - 19999 & 79,2 & 17,2 & 3,6 & 82,3 & 4,2 & 9,6 & 1,0 \\
\hline $20000-49999$ & 79,9 & 16,7 & 3,5 & 80,7 & 5,8 & 8,1 & 2,2 \\
\hline $50000-99999$ & 74,5 & 21,1 & 4,4 & 86,1 & 2,6 & 8,9 & 0,2 \\
\hline $100000+$ & 69,4 & 25,8 & 4,8 & 82,5 & 4,5 & 7,4 & 1,8 \\
\hline Slovakia & 84,0 & 13,0 & 3,0 & 82,0 & 4,9 & 8,2 & 2,4 \\
\hline
\end{tabular}

Tab 12. Religious structure of urban and rural population of Slovakia (2001). 
The 2001 Census demonstrates higher religiousness rate of the rural area than that of cities $(93 \%$ vs. $77 \%)$, which decreases with the increase of size of municipalities (graph 10). It dropped below $70 \%$ in our two biggest cities and the population group with no religion amounts to as much as $25.8 \%$ (tab. 13 ).

The Roman-Catholic population distinctly prevails both in number and relative representation. In $2001,68.9 \%$ of total population and $82 \%$ of religious population adhered to this Church. The comparative representation of Roman-Catholics in rural or urban areas is not much different. Roman-Catholics constitute a profile population of Slovakia. The highest shares in total believers are the Roman-Catholics in size categories of municipalities with population from 2 thousand to 5 thousand $(88.5 \%)$ and from 50 thousand to 100 thousand $(86.1 \%)$. The lowest are the shares in the smallest size categories: $49.9 \%$ in municipalities with population less than 200. It is caused by the presence of a high share of the Greek Catholics or Evangelicals in such municipalities.

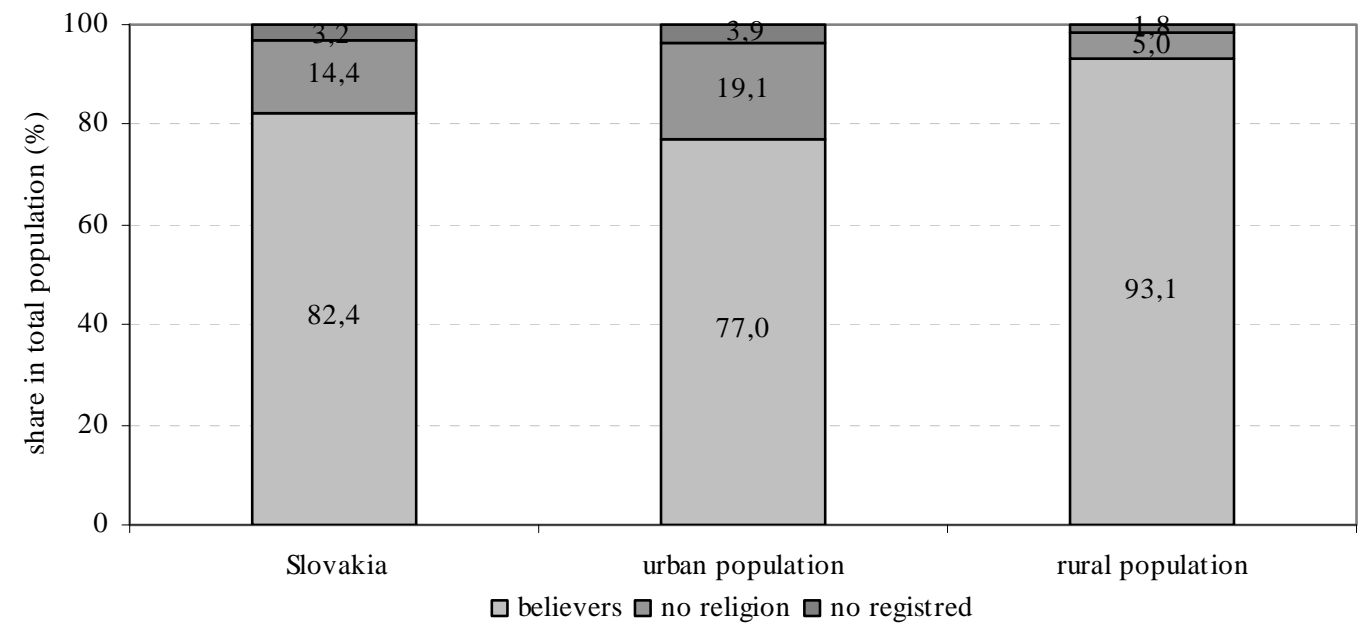

Graph 10. Religiousness of urban and rural population of Slovakia (2001).

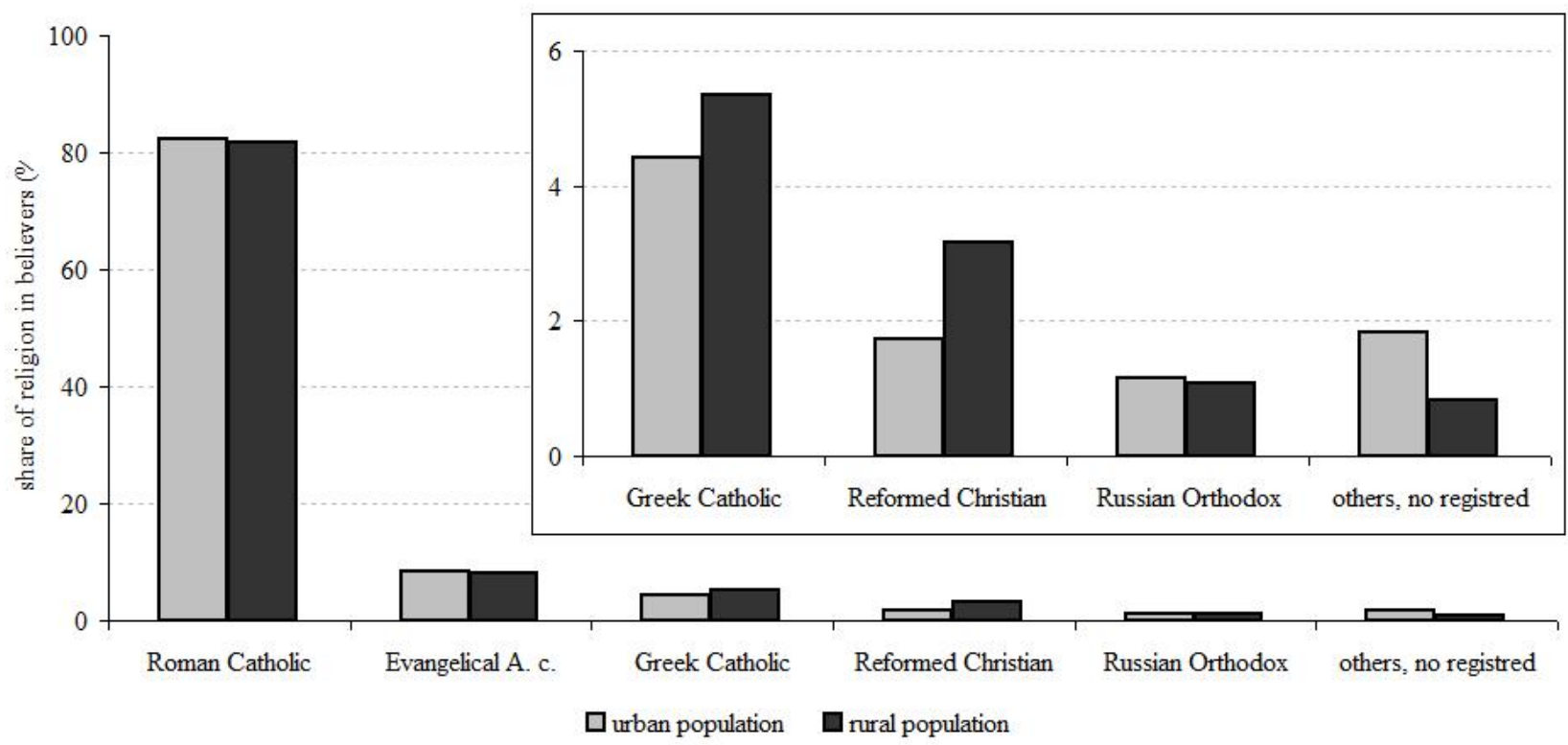

Graph 11. Religious structure of urban and rural population of Slovakia (2001).

The second most populous and spread religion is the Evangelical one of Augsburg confession: $6.93 \%$ of total population and $8.25 \%$ of total believers. This confession is more represented in rural populations but the shares of believers only differ by 0.52 of percent point. The highest shares in total believers were found in size categories of municipalities with population below 1 thousand (over 10\%), in municipalities with population below 200 where it is even $16.2 \%$. High share was also observed in smaller Slovak cities with population from 1 thousand to 
20 thousand $(9.6 \%)$ while the lowest are in municipalities with population from 1 thousand to 5 thousand (less than $6 \%$ ).

The third most populous Church in Slovakia is the Greek Catholic with $4.09 \%$ of all population and $4.86 \%$ of believers. It is often evaluated along with the Orthodox religion as they have a common past. The Orthodox religion is our fifth with $0.94 \%$ of members of overall population living in Slovakia, and $1.11 \%$ of believers. Greek Catholics concentrate in the rural area with share higher by 0.92 percent point while the Orthodox churchgoers enjoy a somewhat higher share in cities ( 0.08 of percent point). Greek Catholics are most frequently represented in municipalities with population below 500 (over 10\%), in municipalities with population below 200 where they amount to even $21.3 \%$ of believers. The lowest share of Greek Catholics (less than $3 \%$ ) is in municipalities with population from 2 thousand to 5 thousand and from 50 thousand to 100 thousand.

Our fourth most populous religion i.e. the Reformed Christian is also concentrated in a certain territorial enclave. It amounts to $2.04 \%$, out of total population and $2.43 \%$ from all believers. This religion is distinctly linked to the rural area with the share of $3.17 \%$ believers against only $1.73 \%$ believers in cities. The highest share was observed in municipalities with population below 1 thousand (more than $4 \%$ ), including the highest $(4.4 \%)$ in municipalities with population between 200 and 499 . The lowest share $(0.2 \%)$ lives in Slovak cities with population between 50 thousand and 100 thousand.

Shares of other religions are below $1 \%$ and linked prevailingly to urban environment where migration and elevated anonymity causes that the religious structure of population is rather variegated.

\subsection{Educational structure}

Studying shares of individual categories formed according to the maximum achieved education in population older than 15 years, population groups with elementary education, secondary education without maturity examinations, secondary education with maturity examinations and university education represented $26.4 \%, 29.4 \%, 32.1 \%$, and $9.8 \%$ respectively (Tab. 13).

Urban population is remarkable for higher educational level as demonstrated in tab. 13. The greatest differences appear in the shares of population with elementary education; it is highest in the rural area (34.8\%). Shares decrease with the increasing educational level. University graduates amount to only $4.2 \%$ of population. The highest share of population with secondary education concluded by the maturity examinations $(37 \%)$ is in the cities. Distinctly high is also the share of population with university education $(14.1 \%)$ as cities, apart from superior schooling, also offer the options of employment for the graduates.

\begin{tabular}{|c|c|c|c|c|c|}
\hline & \multicolumn{5}{|c|}{ Share of population older than 15 years by level of education ( $\mathrm{v} \%)$} \\
\hline & Primary & $\begin{array}{c}\text { Secondary } \\
\text { without } \\
\text { leaving } \\
\text { examination }\end{array}$ & $\begin{array}{c}\text { Secondary } \\
\text { with leaving } \\
\text { examination }\end{array}$ & University & $\begin{array}{c}\text { Without } \\
\text { school } \\
\text { education }\end{array}$ \\
\hline urban & 19,9 & 26,2 & 37 & 14,1 & 0,2 \\
\hline rural & 34,8 & 33,6 & 25,5 & 4,2 & 0,5 \\
\hline 0 - 199 & 44,4 & 30,7 & 20,4 & 2,8 & 0,5 \\
\hline $200-499$ & 37,9 & 33,5 & 23,6 & 3,2 & 0,6 \\
\hline $500-999$ & 35,4 & 33,7 & 25,1 & 3,9 & 0,6 \\
\hline 1000 - 1999 & 33,7 & 33,9 & 26,2 & 4,5 & 0,5 \\
\hline 2000 - 4999 & 32,7 & 33,2 & 27,1 & 5,2 & 0,5 \\
\hline $5000-9999$ & 26,3 & 30,7 & 32,8 & 7,8 & 0,6 \\
\hline 10000 - 19999 & 23,4 & 29,5 & 35,4 & 9,4 & 0,2 \\
\hline 20000 - 49999 & 20,8 & 27,8 & 37,4 & 11,6 & 0,3 \\
\hline 50000 - 99999 & 17,3 & 25,2 & 38,5 & 15,9 & 0,1 \\
\hline $100000+$ & 15,9 & 20,6 & 38,1 & 21,9 & 0,1 \\
\hline Slovakia & 26,4 & 29,4 & 32,1 & 9,8 & 0,4 \\
\hline
\end{tabular}

Tab 13. Educational structure of Slovak population - inhabitants older than 15 years (2001).

Percentages of individual categories are determined by age structure of population, as the share of population with elementary education only is higher in older categories 
concentrated in rural area than in urban population with a notable share of population in productive age.

Tab. 13 reveals that the educational level of population increases with the increasing size of municipality. The highest share of population older than 15 with elementary education $(44.4 \%)$, was found in the smallest size category of municipalities with population below 200; in case of the secondary education without maturity examinations it was in municipalities with population between 1 and 2 thousand (33.9\%); in case of secondary education with maturity examinations it was in municipalities with population between 50 and 100 thousand (38.5\%); and in case of university education it was in our biggest cities Košice a Bratislava: $21.9 \%$ of population older than 15. The highest percentage of population lacking any education is in municipalities with population below 10 thousands; these size categories are characterized by above average shares (more than $0.4 \%$ ).

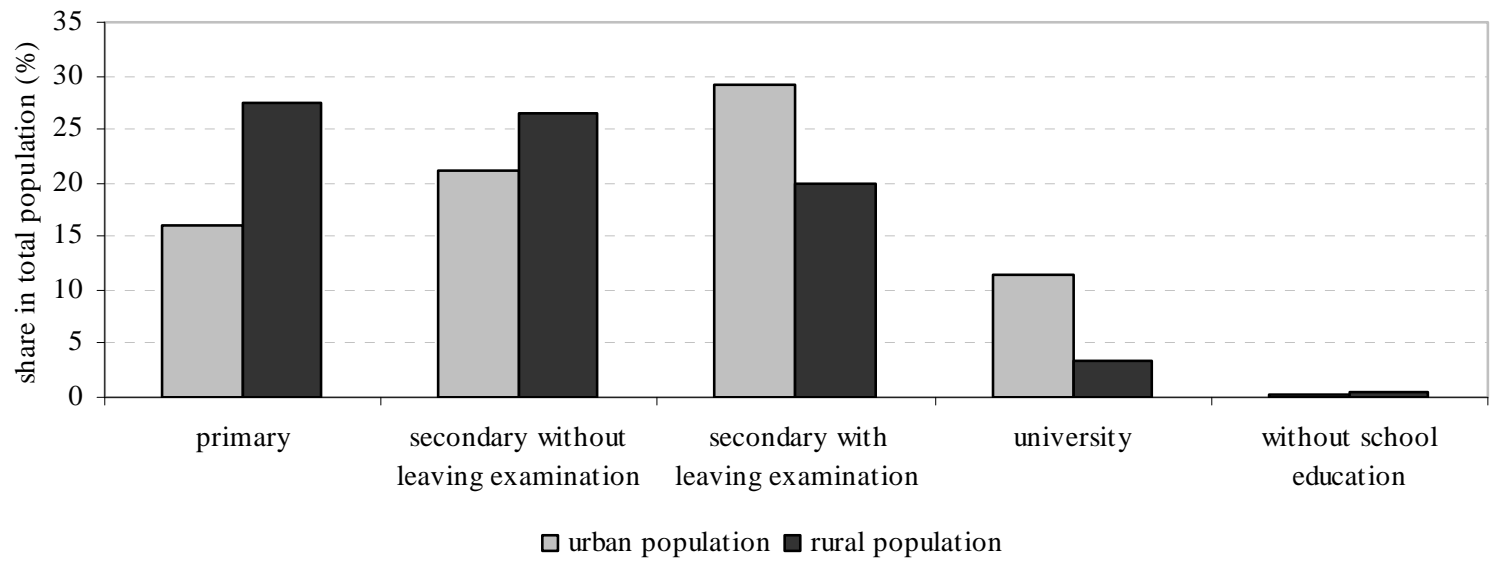

Graph 12. Share of inhabitants by level of education - urban and rural population of Slovakia (2001).

\section{Conclusion}

The aim of this analysis was to disclose or verify differences in demographic behaviour and formation of population structures of rural and urban populations in dependence, if any, on size of municipality. Hypothesis presented at the beginning that urban and rural populations are two different populations sets controlled by their proper laws. While in a more conservative rural area, effects of observed traditions and usage are quite obvious, urban population adopts the modern trends existing in the society including secularisation, increased individualism, etc.

Decreased fertility rate, shift of fertility to higher ages because of individual life trajectories preferred to the foundation of a family are typical for the urban environment. The model of late nuptiality and that of one- or maximum two-child family in cities is in contrast to fertility realized in lower age and two- or more chilled family model preferred in rural area. Urban environment is appropriate for informal partnerships. The share of children born out of wedlock also proves this fact. Negative population phenomena like divorce and abortion rates differ. Anonymous urban environment supports divorce as such and its acceptation is higher than in the rural area just like abortion is more positively assessed in cities.

Natural population decrease is typical for rural population and it is compensated by the migration increase of bigger municipalities. However, the smallest municipalities with population below 200 are deemed to disappear or they will be exploited as recreation areas in future. In the consequence of suburbanization processes and situation in housing market, the population number in our big cites also decreases.

Assumption that formation of population structures depends on size of municipality was also confirmed and structure of urban and rural settlements are different. A good example is the concentration of Hungarian, Ruthenian, and Roma ethnicities in the smallest municipalities while less populous ethnic minorities such as the Czech and German are spatially linked to urban areas of Slovakia. The distribution of individual ethnicities is also connected with religious, age and educational structures. 
Younger population age structure exists in urban areas, ageing processes are more intensive in rural area and above all in the smallest settlements. Cities, and especially the group of the biggest cities, boasts a higher educational level of population.

Some significant facts that may modify the obtained knowledge should not be ignored in these assessments. The nature of sets of urban and rural settlements just like size categories of municipalities is only a matter of convention. Boundaries between them are not as sharp as the statistics may suggest. These boundaries are often subject to disputes of experts. It means that demographic behaviour and formation of population structures should be interpreted in similar transiting forms.

The most intensive urbanization processes in Slovakia took place in the latter half of the $20^{\text {th }}$ century. The first and sometimes also the second generation of population that migrated to cities from the rural area preserved certain features of the demographic behaviour they brought from the original environment what can also reflect in behaviour of urban population.

On the other side, quite notable suburbanization processes proceed in hinterlands of our biggest cities. These processes mean that the demographic behaviour of urban population is brought to the rural area. Presumably, the differences in demographic behaviour of population and formation of population structures in case of the studied sets will progressively diminish.

This contribution was supported by Grant UK No. UK/454/2010 „Regional types of rural municipalities in Slovakia“.

\section{References}

[1] Atlas obyvatel'stva Slovenska (2006). Bratislava: Univerzita Komenského

[2] BECK, U. (2004). Riziková společnost. Na cestě k jiné moderné. Praha: SLON.

[3] BECKER, G. S. (1962). Investment in Human Capital: A Theoretical Analysis. Journal of Political Economy, 70, 9-49.

[4] BEDNÁRIK, R. (1995). Sociologické aspekty religiozity na Slovensku. In Fenomén národnosti (etnicity) a náboženstva $v$ demografii strednej Európy. Zborník príspevkov 5. demografickej konferencie (pp. 4-9). Bratislava: Slovenská štatistická a demografická spoločnost'.

[5] BENEŠOVÁ, V. (2001). Současné demografické změny podle výsledků sociologických výzkumů. Demografie, 43(2), $111-124$.

[6] BEZÁK, A. (1998). Dynamika rastu mestského a vidieckeho obyvatel'stva na Slovensku v období 1970-1995. In Dubcová, A. (Ed.), Geografické informácie 5 (pp. 8-17). Nitra: Univerzita Konštantína Filozofa.

[7] BILLARI, F.C., KULU, H. (2004). Multilevel Analysis of Internal Migration in a Transitional Country: The Case of Estonia. Regional Studies, 38, 679-696.

[8] BLAŽEK, J. (1996). Meziregionální rozdíly v ČR v transformačním období. GeografieSborník ČGS, 101(4), 265-277.

[9] BOTÍKOVÁ, M. et al. (1997). Tradície slovenskej rodiny. Bratislava: Veda.

[10] COLEMAN, J.S. (1988). Social Capital in the Creation of Human Capital. American Journal of Sociology, 94, 95-120.

[11] CUPEROVÁ, K., FILADELFIOVÁ, J. (2000). Rôznorodost' demografického vývoja $\checkmark$ Európe. Bratislava: Medzinárodné stredisko pre štúdium rodiny.

[12] DUBCOVÁ, A., LAUKO, V., TOLMÁČI, L. (2006). Humánna geografia Slovenskej republiky. Bratislava: KARTPRINT.

[13] FIALA, T. (2001): Vývoj manželské plodnosti prvního pořadí v České republice během posledních padesáti let. Demografie, 43(2), 93 - 110. 
[14] GABZDILOVÁ, S. (1995). Vzdelanostná úroveň obyvatel'stva Slovenskej republiky (so zameraním na vysokoškolákov) vo vzt’ahu k etnickému členeniu. In Fenomén národnosti (etnicity) a náboženstva $v$ demografii strednej Európy. In Fenomén národnosti (etnicity) a náboženstva $v$ demografii strednej Európy. Zborník príspevkov 5. demografickej konferencie (pp. 19-25). Bratislava: Slovenská štatistická a demografická spoločnost'.

[15] HRUBÝ, J. (1997). Problematika prirodzeného prírastku obyvatel'stva vo vzt'ahu k vidieku. Slovenská štatistika a demografia 7(1), 40 - 47.

[16] HRUBÝ, J. (1999). Vidiek v demografickej klasifikácií a vývojových zmenách. In Blass, G., M. Kubánková, I. Námerová (Eds.), Rozvoj vidieka a problematika vidieckeho obyvatel'stva. Zborník č. 14 (pp. 86-91). Bratislava: Slovenská akadémia pol'nohospodárskych vied.

[17] ILLNER, M. (1992). K sociologickým otázkám místní správy. Sociologický časopis, 28, 480 -492 .

[18] JANC, K. (2006). Human and Social Capital in Poland - spatial diversity and relations. In Komornicki, T., K. Czapiewski (Eds.), Core and peripheral regions in Central and Eastern Europe, EUROPA XXI, 14, (pp. 39-55). Warszawa: PTG, IGiPZ PAN.

[19] JURČOVÁ, D. (2005). Slovník demografických pojmov. Bratislava: INFOSTAT.

[20] MARENČÁKOVÁ, J. (2001). Vel'kost' obcí Slovenska ako diferenciačný faktor vybraných populačných javov. In Fenomén národnosti (etnicity) a náboženstva $v$ demografii strednej Európy. In Fenomén národnosti (etnicity) a náboženstva $v$ demografii strednej Európy. Zborník príspevkov 8. demografickej konferencie (pp. 130-137). Bratislava: Slovenská štatistická a demografická spoločnost'.

[21] MATLOVIČ, R. (2005). Geografia obyvatel'stva Slovenska so zretel'om na rómsku minoritu. Prešov: Fakulta humanitných a prírodných vied PU.

[22] MICHÁLEK, A. (2000). Rozvodovost', jej príčiny, dôsledky, vývoj a regionálne diferencie. Slovenská štatistika a demografia, 10(3), 24 - 34.

[23] MLÁDEK, J. (1992). Základy geografie obyvatel'stva. Bratislava: SPN.

[24] MLÁDEK, J. (1995). In Fenomén národnosti (etnicity) a náboženstva v demografii strednej Európy. In Fenomén národnosti (etnicity) a náboženstva $v$ demografii strednej Európy. Zborník príspevkov 5. demografickej konferencie (pp. 98-104). Bratislava: Slovenská štatistická a demografická spoločnost'.

[25] MLÁDEK, J. et al. (1998). Demografia Slovenska. Vývoj obyvatel'stva, jeho dynamika, vidiecke obyvatel'stvo. Bratislava: Univerzita Komenského, Bratislava.

[26] MLÁDEK, J. KUSENDOVÁ, D., MARENČÁKOVÁ, J., PODOLÁK, P., VAŇO, B. (2006). Demografická analýza Slovenska. Bratislava, Univerzita Komenského.

[27] MLÁDEK, J., MARENČÁKOVÁ, J., ŠIROČKOVÁ, J. (2006). Demografické správanie vysokoškolákov Slovenska. 1. čast' - reprodukčné správanie. In Slovenská štatistika a demografia, 16(1), 22 - 48.

[28] MLÁDEK, J., MARENČÁKOVÁ, J., ŠIROČKOVÁ, J. (2006). Demografické správanie vysokoškolákov Slovenska. 2. čast' - rodinné správanie. Slovenská štatistika a demografia, 16(2), $71-88$.

[29] MLÁDEK, J., ŠIROČKOVÁ, J. (2002). Vplyv urbanizácie na rozvodovost' obyvatel'stva Slovenska. In Geografické informácie 7, (pp. 177-186). Nitra: Univerzita Konštantína Filozofa.

[30] MORAVANSKÁ, K. (2005). Changes in Slovak countryside human potential during the transformation period. Agricultural Economics. 51(12), 575-584.

[31] OECD (2001). The Well-being of Nations. The role of Human and Social Capital. Paris: OECD Publications

[32] PASTOR, K. (1995). Národnost' a náboženstvo v štatistickom zist'ovaní (Metodologické poznámky). In Fenomén národnosti (etnicity) a náboženstva v demografii strednej Európy. In 
Fenomén národnosti (etnicity) a náboženstva $v$ demografii strednej Európy. Zborník príspevkov 5. demografickej konferencie (pp. 112-118). Bratislava: Slovenská štatistická a demografická spoločnost'.

[33] RYŠAVÝ, Z. et al. (1990). Problémy rozvoje venkovského osídlení, malých a středne velkých měst Československa a jejich demografické struktúry. Praha: Československá demografická společnost při ČSAV.

[34] STEHLÍKOVÁ, B. (1998). Vymedzenie pojmov mesto a dedina pomocou fuzzy množín. Slovenská štatistika a demografia, 8(2), 4-11.

[35] Štatistický úrad Slovenskej republiky: Stav a pohyb obyvatel'stva v Slovenskej republike 2001, 2002, 2003., Bratislava.

[36] Štatistický úrad Slovenskej republiky: Sčítanie obyvatel'ov, domov a bytov 2001. Definitívne výsledky za SR, NUTS2, kraje, okresy a obce., Bratislava, 2003.

[37] ŠVECOVÁ, A. (1999). Dynamika obyvatel'ov a rastové typy miest Slovenska v rokoch 1985 - 1995. In Minár, J., M. Trizna, M. (Eds.), Teoreticko - metodologické problémy geografie, príbuzných disciplín a ich aplikácie (263-272). Bratislava: Univerzita Komenského.

[38] ZUBRICZKÝ, G. (2004). Vývoj obyvatel'stva vidieckych obcí Slovenska v transformačnom období 1991 - 2001. In Acta Facultatis Rerum Naturalium Universitatis Comenianae, Geographica No. 45 (pp. 55 - 64). Bratislava: Univerzita Komenského. 